Prepared in cooperation with the U.S. Environmental Protection Agency

\title{
Assessment of Uncontained Zequanox Applications for Zebra Mussel Control in a Midwestern Lake
}

Open-File Report 2019-1126 



\section{Assessment of Uncontained Zequanox Applications for Zebra Mussel Control in a Midwestern Lake}

By James A. Luoma, Diane L. Waller, Todd J. Severson, Matthew T. Barbour, Jeremy K. Wise, Eric G. Lord, Lynn A. Bartsch, and Michelle R. Bartsch

Prepared in cooperation with the U.S. Environmental Protection Agency

Open-File Report 2019-1126 


\title{
U.S. Department of the Interior DAVID BERNHARDT, Secretary
}

\author{
U.S. Geological Survey \\ James F. Reilly II, Director
}

U.S. Geological Survey, Reston, Virginia: 2019

For more information on the USGS - the Federal source for science about the Earth, its natural and living resources, natural hazards, and the environment-visit https://www.usgs.gov or call 1-888-ASK-USGS.

For an overview of USGS information products, including maps, imagery, and publications, visit https://store.usgs.gov.

Any use of trade, firm, or product names is for descriptive purposes only and does not imply endorsement by the U.S. Government.

Although this information product, for the most part, is in the public domain, it also may contain copyrighted materials as noted in the text. Permission to reproduce copyrighted items must be secured from the copyright owner.

Suggested citation:

Luoma, J.A., Waller, D.L., Severson, T.J., Barbour, M.T., Wise, J.K., Lord, E.G., Bartsch, L.A., and Bartsch, M.R., Assessment of uncontained Zequanox applications for zebra mussel control in a Midwestern lake: U.S. Geological Survey Open-File Report 2019-1126, 21 p., https://doi.org/10.3133/ofr20191126.

ISSN 2331-1258 (online) 


\section{Acknowledgments}

This study was funded with U.S. Environmental Protection Agency Great Lakes Restoration Initiative Grant and U.S. Geological Survey (USGS) appropriated funds.

The authors of this report thank Seth Donovich, Carrie Link, and others from Marrone Bio Innovations for their invaluable technical support, assistance, and outreach during this study, specifically during the Zequanox applications. We thank Matt Claucherty, David Edwards, and other staff from the Tip of the Mitt Watershed Council and Darrin McCullough and other staff from the Michigan Department of Environmental Quality for their assistance in study coordination, logistics, and permitting. The authors of this report thank Dr. Barbara Bennie (University of Wisconsin-La Crosse) for considerable assistance in statistical analyses, data interpretation, and reporting.

The authors of this report thank Patty Reis (USGS Upper Midwest Environmental Sciences Center) who spent many hours carefully analyzing tissue samples for glycogen content and Dr. Brian Gray (USGS Upper Midwest Environmental Sciences Center) for considerable assistance in statistical analyses, data interpretation, and reporting. 



\section{Contents}

Acknowledgments ……...................................................................................................................

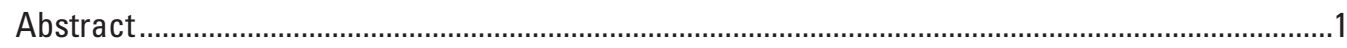

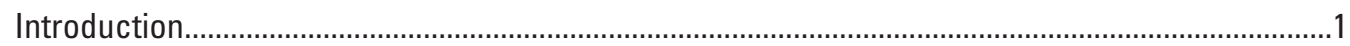

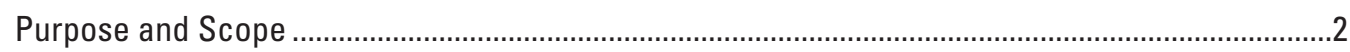

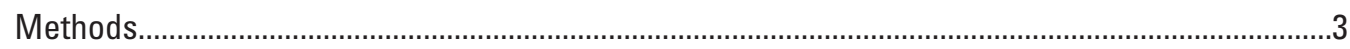

Study Location and Treatment Plots ................................................................................

Zebra Mussel Collection and Handling .............................................................................

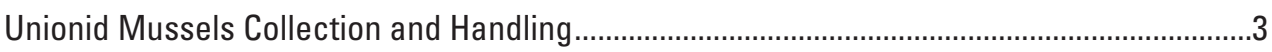

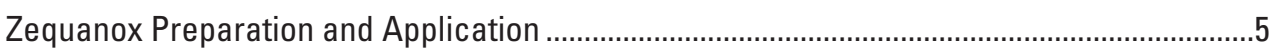

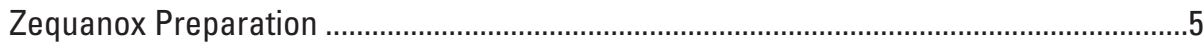

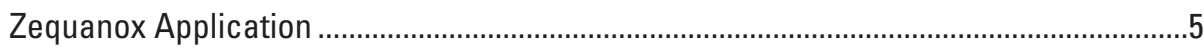

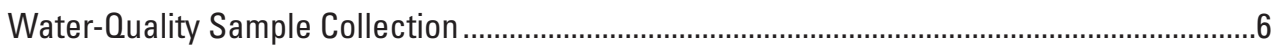

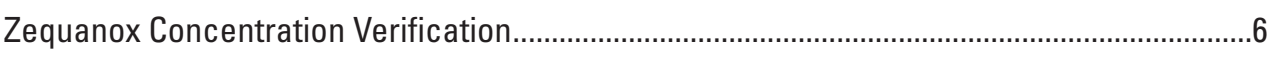

Zebra Mussel Density Sampling .......................................................................................

Zebra Mussel Mortality Assessments .................................................................................

Unionid Mussel Survival and Condition Assessments ..........................................................

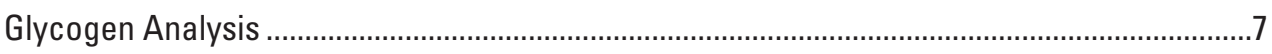

Data Analyses..............................................................................................................

Assessment of Uncontained Zequanox Applications ...................................................................

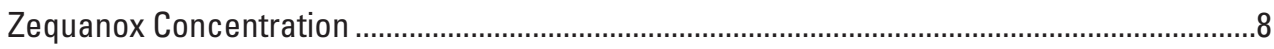

Water-Quality Conditions................................................................................................

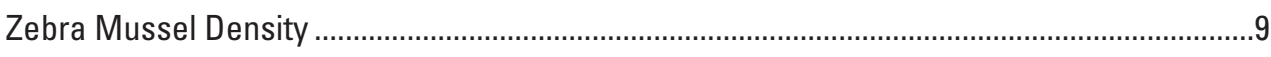

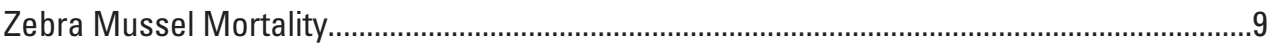

Zebra Mussel Lengths...................................................................................................

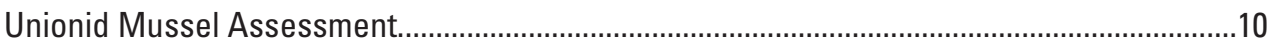

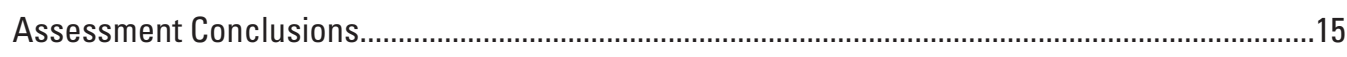

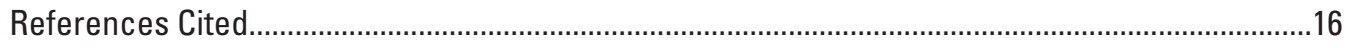

Appendix 1. Detailed Sampling Locations by Treatment for Each Test Plot................................19

\section{Figures}

1. Map showing Round Lake, Emmet County, Michigan, and test plot locations (with plot zone detail) where uncontained Zequanox applications were completed................. 4

2. Photograph showing application system used to apply Zequanox suspensions to test plots in Round Lake, Emmet County, Michigan.

3. Graph showing mean and standard deviation Zequanox concentrations in treated and control plots during the 8-hour uncontained Zequanox applications at Round Lake, Emmet County, Michigan 


\section{Tables}

1. Mean and standard deviation of water-quality properties measured in 2017 during the Zequanox exposure and the 30-day postexposure periods at Round Lake, Emmet County, Michigan.

2. Mean and standard deviation density of live zebra mussels in treatment plots before and after Zequanox exposure at Round Lake, Emmet County, Michigan

3. Mean and standard deviation percent mortality of caged zebra mussels that were exposed during uncontained Zequanox applications at Round Lake, Emmet County, Michigan

4. Mean and standard deviation shell length of live zebra mussels in quadrat samples from zones of Zequanox-treated and control plots at Round Lake, Emmet County, Michigan

5. Mean and standard deviation percent survival of nonbiopsied native fatmuckets, by treatment, that were exposed during uncontained Zequanox applications at Round Lake, Emmet County, Michigan.

6. Mean and standard deviation initial shell length, width, and height of native fatmuckets and change in shell dimensions 1 year after Zequanox exposure at Round Lake, Emmet County, Michigan....

7. Mean and standard deviation glycogen concentration in foot tissue samples of fatmuckets that were exposed to Zequanox during uncontained Zequanox applications at Round Lake, Emmet County, Michigan 


\section{Conversion Factors}

International System of Units to U.S. customary units

\begin{tabular}{|c|c|c|}
\hline Multiply & By & To obtain \\
\hline \multicolumn{3}{|c|}{ Length } \\
\hline centimeter $(\mathrm{cm})$ & 0.3937 & inch (in.) \\
\hline millimeter (mm) & 0.03937 & inch (in.) \\
\hline meter $(\mathrm{m})$ & 3.281 & foot $(\mathrm{ft})$ \\
\hline meter $(\mathrm{m})$ & 1.094 & yard (yd) \\
\hline nanometers (nm) & 0.00000003937 & inch (in.) \\
\hline \multicolumn{3}{|c|}{ Area } \\
\hline square meter $\left(\mathrm{m}^{2}\right)$ & 0.0002471 & acre \\
\hline hectare (ha) & 2.471 & acre \\
\hline square hectometer $\left(\mathrm{hm}^{2}\right)$ & 2.471 & acre \\
\hline square kilometer $\left(\mathrm{km}^{2}\right)$ & 247.1 & acre \\
\hline square centimeter $\left(\mathrm{cm}^{2}\right)$ & 0.001076 & square foot $\left(\mathrm{ft}^{2}\right)$ \\
\hline square meter $\left(\mathrm{m}^{2}\right)$ & 10.76 & square foot $\left(\mathrm{ft}^{2}\right)$ \\
\hline square centimeter $\left(\mathrm{cm}^{2}\right)$ & 0.1550 & square inch $\left(\mathrm{ft}^{2}\right)$ \\
\hline square hectometer $\left(\mathrm{hm}^{2}\right)$ & 0.003861 & section ( 640 acres or 1 square mile) \\
\hline hectare (ha) & 0.003861 & square mile $\left(\mathrm{mi}^{2}\right)$ \\
\hline \multicolumn{3}{|c|}{ Volume } \\
\hline liter $(\mathrm{L})$ & 33.81402 & ounce, fluid (fl. oz) \\
\hline liter $(\mathrm{L})$ & 2.113 & pint $(\mathrm{pt})$ \\
\hline liter $(\mathrm{L})$ & 1.057 & quart (qt) \\
\hline liter $(\mathrm{L})$ & 0.2642 & gallon (gal) \\
\hline cubic meter $\left(\mathrm{m}^{3}\right)$ & 264.2 & gallon (gal) \\
\hline cubic meter $\left(\mathrm{m}^{3}\right)$ & 0.0002642 & million gallons (Mgal) \\
\hline cubic centimeter $\left(\mathrm{cm}^{3}\right)$ & 0.06102 & cubic inch $\left(\mathrm{in}^{3}\right)$ \\
\hline liter $(\mathrm{L})$ & 61.02 & cubic inch $\left(\mathrm{in}^{3}\right)$ \\
\hline cubic meter $\left(\mathrm{m}^{3}\right)$ & 35.31 & cubic foot $\left(\mathrm{ft}^{3}\right)$ \\
\hline cubic meter $\left(\mathrm{m}^{3}\right)$ & 1.308 & cubic yard $\left(\mathrm{yd}^{3}\right)$ \\
\hline cubic meter $\left(\mathrm{m}^{3}\right)$ & 0.0008107 & acre-foot (acre-ft) \\
\hline cubic hectometer $\left(\mathrm{hm}^{3}\right)$ & 810.7 & acre-foot (acre-ft) \\
\hline \multicolumn{3}{|c|}{ Flow rate } \\
\hline kilometer per hour $(\mathrm{km} / \mathrm{h})$ & 0.6214 & mile per hour $(\mathrm{mi} / \mathrm{h})$ \\
\hline liter per minute $(\mathrm{L} / \mathrm{m})$ & 0.2641721 & gallon per minute (gal/m) \\
\hline meter per second $(\mathrm{m} / \mathrm{s})$ & 2.23694 & miles per hour $(\mathrm{mi} / \mathrm{h})$ \\
\hline \multicolumn{3}{|c|}{ Mass } \\
\hline milligram (mg) & 0.00003527 & ounce, avoirdupois (oz) \\
\hline $\operatorname{gram}(\mathrm{g})$ & 0.03527 & ounce, avoirdupois (oz) \\
\hline kilogram (kg) & 2.205 & pound avoirdupois (lb) \\
\hline
\end{tabular}

Temperature in degrees Celsius $\left({ }^{\circ} \mathrm{C}\right)$ may be converted to degrees Fahrenheit $\left({ }^{\circ} \mathrm{F}\right)$ as

$$
{ }^{\circ} \mathrm{F}=\left(1.8 \times{ }^{\circ} \mathrm{C}\right)+32 .
$$




\section{Datum}

Horizontal coordinate information is referenced to the World Geodetic System of 1984 (WGS 84).

\section{Supplemental Information}

Specific conductance is given in microsiemens per centimeter at 25 degrees Celsius $(\mu \mathrm{S} / \mathrm{cm}$ at $\left.25^{\circ} \mathrm{C}\right)$.

Concentrations of chemical constituents in water are given in milligrams per liter (mg/L).

Turbidity is given in nephelometric turbidity units (NTU).

Hardness and alkalinity are measured in milligrams per liter ( $\mathrm{mg} / \mathrm{L}$ ) as calcium carbonate $\left(\mathrm{CaCO}_{3}\right)$.

\section{Abbreviations}

Pf-CL145A Pseudomonas fluorescens strain CL145A

GPS global positioning system

NTU nephelometric turbidity units

DO dissolved oxygen

SD standard deviation 


\title{
Assessment of Uncontained Zequanox Applications for Zebra Mussel Control in a Midwestern Lake
}

\author{
By James A. Luoma, Diane L. Waller, Todd J. Severson, Matthew T. Barbour, Jeremy K. Wise, Eric G. Lord, \\ Lynn A. Bartsch, and Michelle R. Bartsch
}

\section{Abstract}

Zebra mussels (Dreissena polymorpha) are invasive bivalves that have perturbed aquatic ecosystems within North America since their introduction in the mid-1980s. Control of zebra mussels has largely been restricted to raw water conveyance systems and associated infrastructures because few control products are registered for application in surface waters. The biopesticide Zequanox was registered in 2014 by the U.S. Environmental Protection Agency for controlling dreissenid mussels (zebra and quagga mussels (Dreissena rostriformis bugensis) in surface waters. Previous Zequanox applications in surface waters have used vertical impermeablemembrane barriers to contain treated water. Studies have indicated that uncontained applications may be successful if Zequanox suspensions of the correct viscosity are applied to facilitate the creation of stratified benthic treatment layer. In this study, Zequanox was applied to replicate 0.30 -hectare plots within a small inland lake using a custom-engineered, boat-mounted application system to determine if uncontained Zequanox applications could be used to manage zebra mussel populations and to protect native unionid mussels within zebra mussel infested waters. To determine success, the following specific objectives were investigated during, 30 days after, and/or 1 year after Zequanox exposure: (1) evaluate Zequanox concentrations during exposure; (2) monitor water quality during and after exposure; (3) evaluate the mortality of zebra mussels that were caged within treatment zones during the exposures; (4) evaluate the densities of naturally occurring zebra mussels with treatment zones before and after Zequanox exposure; and (5) evaluate the survival, condition, and dreissenid infestation of native mussels in the treatment zones before and after Zequanox exposure. Zequanox rapidly dissipated from the treated plots, resulting in no appreciable treatmentrelated mortality of zebra mussels and insignificant impacts to water quality. Zequanox exposure-related impacts to native mussels were not observed.

\section{Introduction}

Zebra mussels (Dreissena polymorpha) are highly invasive, ecosystem-altering bivalves that have adversely impacted invaded waterways (Lewandowski and Stańczykowska, 2014; Orlova, 2014; Sousa and others, 2014; Benson and others, 2019). Because of their high fecundity, zebra mussels can quickly reach extremely high densities, and a microscopic, free-swimming early life stage allows for anthropogenic transport and rapid dispersal (Mackie and Claudi, 2010; Birnbaum, 2011). Zebra mussels can cause extensive ecological effects; such as, biogeochemical cycle alterations, energy flow disruptions, habitat alterations, shifts in population structures of invertebrate and fish communities, and promotion of harmful algal blooms through selective filtering (Vanderploeg and others, 2001; Orlova and others, 2004; Strayer and others, 2004; Bruesewitz, 2008; Hoyle and others, 2008; Knoll and others, 2008; Vanderploeg and others, 2010; Adlerstein and others, 2013; Colvin and others, 2015). Zebra mussels have also negatively impacted native unionid populations through competition for food resources and other effects related to biofouling (Ricciardi and others, 1998; Strayer and Malcom, 2007).

Zebra mussels readily colonize hard surfaces, causing biofouling and corrosion of structures and equipment such as trash screens, dams, docks, boats, engines, and navigational aids (Mackie and Claudi, 2010; Chakraborti and others, 2013). The cost to mitigate the impacts of zebra mussels to infrastructure has been estimated at $\$ 100$ million per year (De Leon, 2008). Remediation costs in the United States will likely increase as dreissenid mussels - zebra and quagga mussels (Dreissena rostriformis bugensis) - become established in waters west of the Continental Divide.

Chlorination quickly became the primary means to combat zebra mussel fouling in industrial water systems (Mackie and Claudi, 2010; Chakraborti and others, 2013) and although effective, the use of chlorine has environmental consequences. Chlorine reacts with organic matter and can result in the 
production of carcinogenic disinfection by-products such as trihalomethanes and haloacetic acids (Dojlido and others, 1999; Nokes and others, 1999; Richardson and others, 2007). The hazards associated with increased chlorine use and the concomitant increase of disinfection by-products increases environmental concerns (Molloy, 1998; Molloy and others, 2013b).

In the 1990s, efforts were made to discover an environmentally compatible chlorine replacement for use in dreissenid mussel biofouling treatments. Hundreds of microorganisms were screened for dreissenid mussel toxicity, and a single bacterial strain, Pseudomonas fluorescens strain CL145A ( $P f$-CL145A), was determined to have potential for development into an environmentally compatible and selective control tool (Molloy, 1998; Mayer, 2011; Molloy and others, 2013a,b). Zequanox, a biopesticide containing 50 percent dead $P f$-CL145A cells as the active ingredient, was developed by Marrone Bio Innovations (Davis, California) and is registered with the U.S. Environmental Protection Agency (registration number 84059-15) for defined discharge system and surfacewater applications (Weber, 2015; Marrone Bio Innovations, 2019). As of 2019, Zequanox is approved for application in 41 states, with ongoing research and label expansions in the United States, Canada, Europe, and South America (Carrie Link, Marrone Bio Innovations, written commun., 2019). Various experimental Zequanox applications have been completed in surface waters that used barriers to contain treated waters (Luoma and others, 2015b; Weber, 2015; Whitledge and others, 2015; Luoma and Severson, 2016). Zequanox also was applied within a containment barrier during a rapid-response action to eradicate zebra mussels from a newly infested lake (Christmas Lake, Hennepin County, Minnesota [not shown]; Lund and others, 2018).

Several studies evaluated subsurface applications that were designed to target the benthic environment to maximize exposure to zebra mussels while reducing the amount of Zequanox required for treatment. No difference in mortality was detected among zebra mussels exposed to either wholewater column or subsurface Zequanox applications in 350-liter (L) tanks (Luoma and others, 2015a).

Whole-water column versus subsurface Zequanox applications were further evaluated using 27-square meter $\left(\mathrm{m}^{2}\right)$ in-lake enclosures (Luoma and Severson, 2016). Results indicated a reduction in zebra mussel mortality ranging from about 13 to 17 percent with subsurface applications; however, the loss in efficacy with the subsurface applications was offset by the need to apply more Zequanox in the whole water column applications (Luoma and Severson, 2016).

Two independent experiments that used subsurface Zequanox applications within enclosures were completed during 2 subsequent years in a small quarry lake. In the first experiment, Zequanox was observed to mix into the upper, untreated portion of the water column within $24-\mathrm{m}^{2}$ enclosures; however, treatment-related mortality of zebra mussels still exceeded 91 percent for zebra mussels attached to benthic substrates and macrophytes and 97 percent for zebra mussels contained within test chambers (Whitledge and others, 2015). In the second experiment, Zequanox was applied to a 324$\mathrm{m}^{2}$ enclosure using subsurface spot treatments, and mortality exceeded 90 percent for zebra mussels within 5 meters (m) of injection points (Whitledge and others, 2015).

Subsurface Zequanox applications also were evaluated in laboratory experiments and replicated $9-\mathrm{m}^{2}$ pond enclosures at temperatures ranging from approximately 9 to 20 degrees Celsius $\left({ }^{\circ} \mathrm{C}\right)$ (Severson and Luoma, 2016). In these experiments, an obvious effect of water temperature on the viscosity of Zequanox suspensions was observed, and a formula was developed for determining temperature-specific Zequanox concentrations that would produce a suspension with the desirable viscosity for subsurface applications in waters with temperatures ranging from 7 to $22{ }^{\circ} \mathrm{C}$ (Severson and Luoma, 2016).

The use of barriers to contain Zequanox-treated water creates logistical difficulties and increases costs associated with barrier acquisition and placement. Previous studies demonstrated the potential use of subsurface applications to reduce the amount of Zequanox required to achieve adequate control, but additional field-scale studies were needed to determine the efficacy and feasibility of uncontained Zequanox applications in surface waters. The purpose of this study was to determine if uncontained Zequanox applications could be used to manage zebra mussel populations and to protect native unionid mussels within zebra mussel infested waters. Specific objectives were investigated during, 30 days after, and/or 1 year after Zequanox exposure and included the following: (1) evaluate the Zequanox concentrations during exposures; (2) monitor the water quality during and after exposures; (3) evaluate of the mortality of zebra mussels that were caged within treatment zones during the exposures; (4) evaluate of the densities of naturally occurring zebra mussels in the treatment zones before and after Zequanox exposure; and (5) evaluate the survival, condition, and dreissenid infestation of native mussels before and after Zequanox exposure.

\section{Purpose and Scope}

The purpose of this report is to describe the assessment of using uncontained Zequanox applications for zebra mussel control using data collected and analyzed by the USGS during and after replicated, uncontained Zequanox applications that were completed on an inland lake in Michigan in 2017 to evaluate the potential use of similar treatments for zebra mussel control, including within waters containing native mussels. Specifically, the assessment includes results of Zequanox concentrations during exposures; water-quality conditions before, during, and after exposures; density, mortality, and lengths of zebra mussels before and after exposures; and survival and condition of native mussels before and after exposures.

Data collected for this study are available in an associated data release (Luoma and others, 2019b). The SAS code 
files and a file describing each SAS code file that were used to analyze data for this study are available in an associated code release (Luoma and others, 2019a).

\section{Methods}

This section of the report describes the study location and treatment plots used in the assessment of uncontained Zequanox applications. Methods are described for animal collection and handling, preparation and application of Zequanox, collection of water samples, verification of Zequanox concentrations, density sampling of zebra mussels, assessing the mortality of zebra mussels, assessing the survival and condition of unionid mussels, glycogen analysis, and data analyses.

\section{Study Location and Treatment Plots}

The study was completed at Round Lake, Emmet County, Michigan (fig. 1), and Zequanox applications were completed on July 27, 29, and 31, 2017. Round Lake is a 135-hectare (ha), soft-bottom lake with a maximum depth of approximately 4.9 m (Lake-Link, Inc., 2019). Eight paired, 0.30-ha treatment plots were selected in the lake (sample size $[n]=4$ treated, $n=4$ control); however, only plots 1 through 6 ( $n=3$ treated, $n=3$ control) were used for this study (fig. 1). The remaining plots ( 7 and 8 ) were not evaluated using the measures described in this report because the extremely soft sediments within these plots, combined with the water depth, resulted in unsafe working conditions. Plots in each paired group (treated and control) were spatially separated by approximately $25 \mathrm{~m}$, and the water depths in the plots ranged from approximately 1.0 to $1.5 \mathrm{~m}$. Potential plot locations were identified in the field, then precise shapefiles were generated from global positioning system (GPS) measurements. The shapefiles were uploaded to an agriculture GPS unit (model FM-750, Trimble Navigation Limited, Sunnyvale, California), which was used to delineate plot boundaries, display preselected navigation lines, and plot the path of the application vessel. Plot corners were located with an accuracy of plus or minus 10 millimeters $(\mathrm{mm})$ using a Trimble Global Navigation Satellite System that consisted of a rover and base station (models T3C3 and R10, Trimble Navigation Limited, Sunnyvale, California) and Trimble Access software (Version 2016.3 Trimble Navigation Limited, Sunnyvale, California). Flexible marker buoys were placed at the plot corners to serve as visual navigation aids and to allow for contact with the application boom without causing damage to the boom or dislodgement of the buoy. Plots were divided into the following three zones: (1) edge, a 1-m wide band inward from the plot boundaries on all sides; (2) fringe, a 3-m wide band on all sides with the outermost perimeter adjacent to the edge zone; and (3) core, the remaining plot area (fig. 1, appendix 1).

\section{Zebra Mussel Collection and Handling}

Zebra mussels (Dreissena polymorpha) adhering to unionid mussels and woody debris were collected from Round Lake, Emmet County, Michigan, approximately 3 weeks before Zequanox applications. Zebra mussels were separated from the substrate by severing their byssal threads with a scalpel. Zebra mussels were then transferred into a wire-mesh cage (approximately $0.9 \mathrm{~m}$ long by $0.6 \mathrm{~m}$ wide by $0.4 \mathrm{~m}$ high) that was constructed according to the methods of Brady and others (2010). The cage was placed in approximately $1.5 \mathrm{~m}$ of water near the boat launch. Zebra mussels were individually inspected 2 days pretreatment to determine their suitability for testing. Mussels were deemed suitable if they resisted opening when gentle opposing pressure was applied to their valves. Twenty-five zebra mussels were placed into uniquely labeled, semirigid, plastic-mesh bags $(20.3$ centimeters $[\mathrm{cm}]$ wide by $25.4 \mathrm{~cm}$ high by $5.1 \mathrm{~cm}$ deep with $0.3 \mathrm{~cm}$ by $0.3 \mathrm{~cm}$ openings). A brick was attached to the bottom of each bag, and a float was tied to the top of each bag to ensure proper orientation while positioned on the lakebed. Six bags were indiscriminately placed within each plot zone.

\section{Unionid Mussels Collection and Handling}

Native unionid mussels (fatmucket [Lampsilis siliquoidea]) were collected from Round Lake during two periods before treatment. Group 1 mussels were collected 3 weeks before treatment, and these mussels were used to assess changes in glycogen levels and growth during the study period. Group 2 mussels were collected about 4 days before treatment, and these mussels were used to assess effects of Zequanox treatment on survival. Mussels were individually marked with shellfish tags (Hallprint, Hindmarsh Valley, Australia) and passive radio frequency identification tags (model HPT23, Biomark Incorporated, Boise, Idaho). A piece of floating fishing line, approximately $25 \mathrm{~cm}$ long, was also fixed to the shells to act as a visual aid to assist in recovery. All materials were attached to the shells using Loctite super glue gel that was quick cured with an accelerant (Zip-Kicker, Pacer Technology, Ontario, California). Individual mussel shell length, width, and height were measured to the nearest $0.1 \mathrm{~mm}$ with a calibrated digital caliper, and the number of adhering zebra mussels were enumerated. The shell length of mussels used in the study ranged from 35.3 to $80.5 \mathrm{~mm}$. A tissue sample, approximately 10 milligrams by wet weight, was collected from the foot of each fatmucket in group 1 using a 14-gauge biopsy needle. The tissue samples were placed into prelabelled cryopreservation vials, flash-frozen in liquid nitrogen, and stored in an ultracold freezer $\left(-80^{\circ} \mathrm{C}\right)$ until analyzed for muscle glycogen content. Fatmuckets in group 1 were transferred to solid-bottom wire mesh cages containing sand substrate; the cages were placed in approximately $1.5 \mathrm{~m}$ 


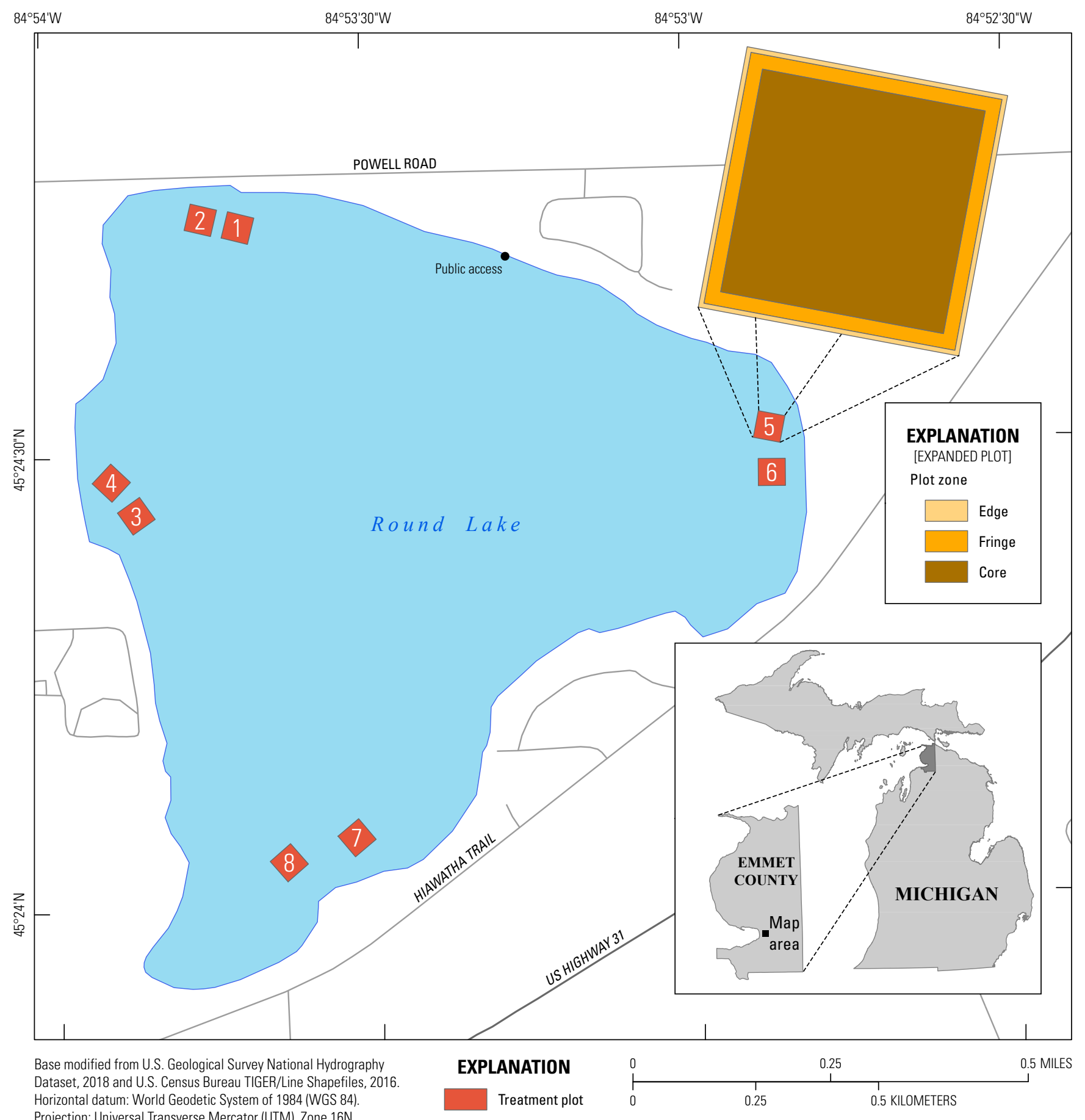

Projection: Universal

Figure 1. Round Lake, Emmet County, Michigan, and test plot locations (with plot zone detail) where uncontained Zequanox applications were completed. Image by Matthew Barbour, U.S. Geological Survey. 
of water adjacent to plot 1 . Approximately 4 days pretreatment, all fatmuckets (groups 1 and 2) were placed into $1-\mathrm{m}^{2}$ quadrats in approximately $1.5 \mathrm{~m}$ of water near the boat launch until indiscriminately distributed to test plots. Approximately 24 to 48 hours before each Zequanox application, 11 biopsied fatmuckets (group 1) and 5 (plots 5 and 6) or 6 (plots 1-4) nonbiopsied fatmuckets (group 2) were hand placed into each of four, $1-\mathrm{m}^{2}$ quadrats that were indiscriminately placed on the lakebed in the core zone of each plot. All quadrats were constructed from $5-\mathrm{cm}$ polyvinyl chloride pipe and secured to the lakebed using rebar stakes.

\section{Zequanox Preparation and Application}

Each application day consisted of the treatment and sampling of one plot pair (one control and one Zequanox-treated plot). Treatment order was randomly assigned, and applications were completed on 3 nonconsecutive days. Zequanox suspensions were prepared and immediately applied below the water surface to target the creation of a stratified $0.75-\mathrm{m}$ treated layer at the bottom of the water column containing 100 milligrams per liter $(\mathrm{mg} / \mathrm{L}$ ) of Zequanox active ingredient. Zequanox applications were completed during calm conditions in the early morning. Control plot applications followed Zequanox applications after the application system was purged of residual Zequanox. Control applications used similar techniques, except lake water was substituted for the Zequanox suspension.

\section{Zequanox Preparation}

The Zequanox used in this study was manufactured, transported, stored, and mixed by Marrone Bio Innovations collaborators. For each application, 500 kilograms of Zequanox was retrieved from a local cold storage facility, transported to the lake, and immediately prepared with lake water into a suspension for application. Target Zequanox suspension concentrations of 17.2 and 17.8 percent (weight/ volume) were calculated and prepared for application based on daily ambient lake water temperature and equation 1 (modified from Severson and Luoma, 2016) as follows:

$$
C=e \frac{T+40.44}{22.34}
$$

where
$C$ is the Zequanox suspension weight/volume concentration, in percent;
$e \quad$ is Eul
$T \quad$ is the ambient lake temperature, in degrees Celsius.

A food-grade, silicone-based defoaming agent (SMS Antifoam, SMS Additive Solutions, LLC, Mount Laurel, New Jersey) was added to each Zequanox suspension ( 0.2 percent volume/volume) to reduce buoyancy resulting from air entrainment. Zequanox suspensions were prepared using the following application system: a diesel-powered, three-phase generator (model MEP-803a, Fremont Division, Dynamic Corporation of America, Bridgeport, Connecticut); a highshear mixer (model ZCO, Quadro Engineering Corporation, Waterloo, Ontario, Canada); interconnected 1,041-L polyethylene intermediate bulk containers; and sections of a $5-\mathrm{cm}$ inside-diameter ethylene propylene diene monomer rubber suction hose. A total of 456 kilograms of Zequanox was required for each application, however, because of retention of Zequanox within the mixing and application systems, 500 kilograms was prepared. To prevent stratification within the bulk containers, a semi-trash pump (model 66520, Champion Power Equipment, Santa Fe Springs, California) was used to continuously recirculate the Zequanox suspension during application. After application, residual Zequanox suspensions were disposed of in accordance with the study permits using a licensed septic hauler and by diluting with lake water.

\section{Zequanox Application}

Zequanox suspensions were applied using a vesselmounted system constructed with design, manufacturing, and assembly support (fig. 2) provided by the Engineering Department at the University of Wisconsin-Platteville. Zequanox suspensions were delivered approximately $0.6 \mathrm{~m}$ above the lakebed using an underwater $3.7-\mathrm{m}$ wide, horizontal distribution manifold fitted with 12 horizontally-depressed, 3-dimensional printed nozzles $(0.5-\mathrm{cm}$ high by $6.7-\mathrm{cm}$ wide orifice). The manifold was suspended in the water column in front of the application vessel. A depth finder (Hummingbird model HDR 650, Johnson Outdoors Marine Electronics, Incorporated, Racine, Wisconsin) and a remote-controlled electric winch were used to monitor and adjust the application depth. The Zequanox application vessel was operated in reverse to reduce mixing of the Zequanox into the water column from boat- and motor-induced turbulence. The delivery system was engineered so that the Zequanox discharge velocity matched the opposing velocity of the application vessel. This design provided conditions favorable for creating a stratified, Zequanox-treated layer at the bottom of the water column. An application speed of 0.44 meter per second was targeted, and 15 parallel transects were required to apply Zequanox over the plot. The GPS navigation system displayed each plot with preselected transect lines, and a paint feature allowed the application vessel operator to visualize where Zequanox had been applied. The application rate of Zequanox was adjusted to target 87 liters per minute using control valves and a flow meter (model MN-ASB70GM-16-430C1.0-TXL1XLZ67, Universal Flow Monitors, Incorporated, Hazel Park, Michigan). 


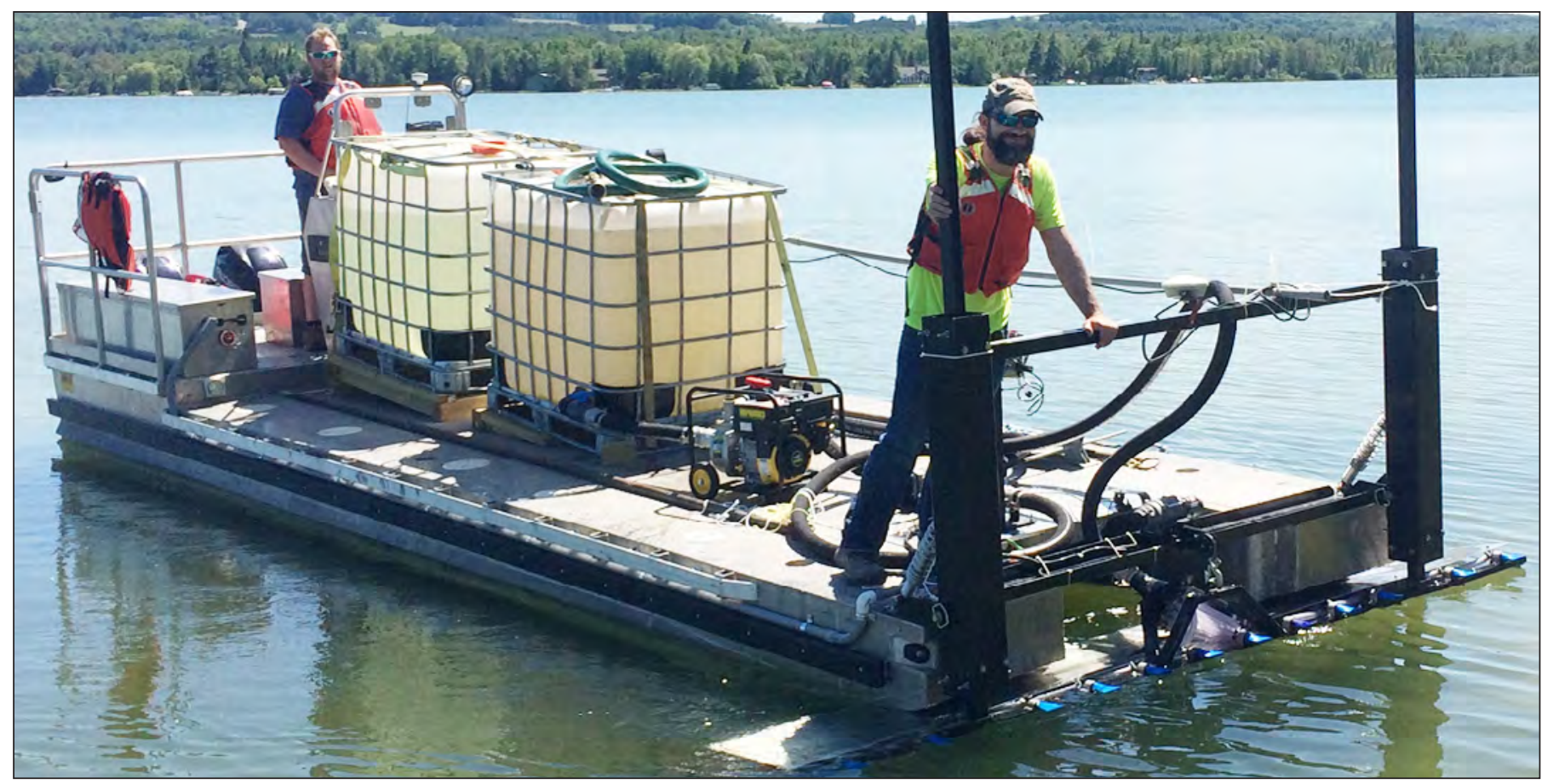

Figure 2. Application system used to apply Zequanox suspensions to test plots in Round Lake, Emmet County, Michigan.

\section{Water-Quality Sample Collection}

Multiparameter water-quality data sondes (Hydrolab model MS5, OTT HydroMet, Loveland, Colorado) were calibrated and placed approximately $0.25 \mathrm{~m}$ above the lakebed near the center of each test plot. The data sondes recorded dissolved oxygen (DO), $\mathrm{pH}$, temperature, and specific conductance every 6 hours throughout the treatment and for approximately 30 days after treatment. Prior to treatment, three sections (76-m long) of color-coded, 4.8-mm inside diameter vinyl tubing were positioned to collect water samples from each plot zone. To prevent the vinyl tubing from becoming plugged, the tubing was connected to a section of polyvinyl chloride pipe that was covered with 600 -micron mesh. The pipe was secured approximately $15 \mathrm{~cm}$ above the lakebed at each sampling location to allow for water sample collection, and the other end of the tubing was terminated at a floating raft anchored approximately $1-\mathrm{m}$ outside of the plot boundary. Peristaltic pumps were attached to each line at the sampling raft and used to purge approximately $1.5 \mathrm{~L}$ of water through each line prior to the collection of approximately $0.5 \mathrm{~L}$ of water for analysis. Water samples were collected at approximately 1, 2, 4, and 8 hours after Zequanox application, except for the 2 -hour samples from control plot 6 , which were not collected because of time constraints and sample time overlap. Water samples were analyzed for DO, $\mathrm{pH}$, temperature, turbidity, specific conductance, and Zequanox concentration. DO and
$\mathrm{pH}$ were measured using a water-quality meter equipped with luminescent optical DO and $\mathrm{pH}$ probes (models HQ40d, LDO 10101, PHC 70501; Hach Company, Loveland, Colorado); temperature was measured with a digital thermometer (Thermapen model Mk4, ThermoWorks Company, American Fork, Utah); turbidity was measured using a hand-held turbidimeter (model 2100Q, Hach Company, Loveland, Colorado); and specific conductance was measured with a hand-held conductivity meter (Accumet model AP75, Fisher Scientific Company, Pittsburg, Pennsylvania). Grab water samples were collected from each test plot prior to treatment and analyzed for total hardness and alkalinity using the ethylenediaminetetraacetic acid titrimetric method (method 2340C; American Public Health Association, 2012) and by titrating to an endpoint of pH 4.5 (method 2320B; American Public Health Association, 2012), respectively.

\section{Zequanox Concentration Verification}

Zequanox concentrations in water samples were determined using a portable spectrophotometer (model DR 3900, Hach Company, Loveland, Colorado) by comparing sample absorbance at 660 nanometers to a zero-intercept linear regression created with a series of five Zequanox standards that ranged in concentration from 25 to $300 \mathrm{mg} / \mathrm{L}$ of active ingredient. 


\section{Zebra Mussel Density Sampling}

The density of live zebra mussels in each zone (core, fringe, edge) of each test plot was assessed prior to treatment and then again approximately 30 days and 1 year after treatment. At all three sampling times, six sediment samples were collected from every zone within each test plot (appendix 1). Quadrat samplers $\left(0.25-\mathrm{m}^{2}\right)$ that were constructed from polyvinyl chloride pipe were placed on the lakebed, GPS coordinates were recorded, and approximately $10 \mathrm{~cm}$ of sediment from within each sampler was placed into a fine mesh bag by wading or snorkeling personnel. Sediment samples were rinsed and sifted through a series of three stacked graduated sieves with 11.3-, 5.6-, and 2.4-mm square openings. For each plot, the number of live zebra mussels retained on each sieve was recorded prior to pooling mussels by zone and sieve size and preserving in 70-percent isopropyl alcohol.

Using a calibrated digital caliper, 25 indiscriminately selected mussels from each pooled group were measured to the nearest $0.1 \mathrm{~mm}$ for shell length. If less than 25 animals were in a pooled group, then all mussels were measured.

\section{Zebra Mussel Mortality Assessments}

Approximately 30 days after treatment, the six mesh bags containing zebra mussels were collected from each plot zone, and the number of live and dead zebra mussels in each bag were recorded. Mortality was defined as failure to resist opening upon the application of gentle opposing pressure applied to the valves. Zebra mussels were pooled by plot, preserved in 70-percent isopropyl alcohol, and 100 indiscriminately selected mussels from each plot were later measured to the nearest $0.1 \mathrm{~mm}$ for shell length using a calibrated digital caliper. Zebra mussels contained in the mesh bags from plots 3 and 4 were not measured for shell length because these mussels were inadvertently discarded. Given that the zebra mussels in the mesh bag samplers were from the same pooled source, the impact of not measuring mussels from plots 3 and 4 was considered negligible.

\section{Unionid Mussel Survival and Condition Assessments}

Approximately 30 days after treatment, fatmuckets were collected from each $1-\mathrm{m}^{2}$ quadrat and assessed for survival. Individual mussels were measured to the nearest $0.1 \mathrm{~mm}$ for length, width, and height with a calibrated digital caliper, and then the number of adhering zebra mussels was enumerated. Previously biopsied mussels were resampled using previously described procedures. Mussels that were alive at 30 days postexposure were returned to their assigned quadrat and evaluated 1 year postexposure. Fatmuckets were collected 1 year postexposure from each $1-\mathrm{m}^{2}$ quadrat and assessed as previously described. Upon completion of the 1 year postexposure data collection, the tags, fishing line, and adhering zebra mussels were removed from the shells of surviving fatmuckets before returning them to the lake.

\section{Glycogen Analysis}

Glycogen content of foot tissue samples of group 1 fatmuckets was determined by measuring the amount of glucose that was enzymatically hydrolyzed from glycogen with a buffered amyloglucosidase solution (item S9144, Sigma-Aldrich Chemical Company, St. Louis, Missouri). Glucose was spectrophotometrically determined using a certified glucose assay reagent (Infinity Hexokinase reagent, Fisher Diagnostics, Middleton, Virginia) and a microplate analysis system (model SPECTRAmax Plus 384, Molecular Devices, San Jose, California). Primary calibration standards were prepared for each batch of 25 samples, and a 7-point calibration curve was created with a National Institute of Standards and Technology traceable, glucose primary standard solution (item G3285, Sigma Chemical Company, St. Louis, Missouri). Each batch of samples contained a minimum of one analyte-free reagent blank sample to assess reagent purity and procedural contamination. Glycogen in each tissue sample was hydrolyzed, with the resulting glucose analyzed in triplicate and reported as a mean. Duplicate tissue samples were not analyzed because of insufficient sample quantity; therefore, procedural triplicate samples of mussel foot tissue from a reference collection were analyzed with each sample batch to assess procedural variability. The mean procedural percent relative standard deviation was 12.1. A known addition of glycogen was added to 5 percent of samples to assess analyte recovery. The percent recovery of the known addition was 105.7 percent (from 86 to 129 percent). The coefficient of determination for the calibration curve for all batches was greater than 0.99 .

\section{Data Analyses}

Data were summarized using simple descriptive statistics generated with SAS software (version 9.4; SAS, 2016) that are available in the associated code release (Luoma and others, 2019a). The associated code release contains SAS code files that summarize and analyze the following: (1) water hardness and alkalinity of water at the time of treatments; (2) waterquality properties during the exposure period; (3) water-quality properties during the postexposure period; (4) the density of live zebra mussels within $0.25-\mathrm{m}^{2}$ quadrats collected from each treatment plot zone at three time points (preexposure, 30 days postexposure, and 1 year postexposure; (5) length of live zebra mussels within $0.25-\mathrm{m}^{2}$ quadrats collected from each treatment plot zone at three time points (preexposure, 30 days postexposure, and 1 year postexposure); (6) survival of caged zebra mussels placed in each treatment plot zone; (7) length of caged zebra mussels placed in each treatment plot zone; (8) Zequanox concentrations observed during the exposure period; (9) survival of nonbiopsied native mussels, positioned within $1-\mathrm{m}^{2}$ quadrats in the core zone of each treatment, at 
30 days and 1 year postexposure; (10) glycogen content of tissue samples, collected from native mussels that were positioned within $1-\mathrm{m}^{2}$ quadrats in the core zone of each treatment, at three time points (preexposure, 30 days postexposure, and 1 year postexposure); and (11) mean shell dimensions of mussels by plot, treatment, and week and shell growth at 1 year (Luoma and Waller, 2019). Generalized linear mixed models, including binomial models and linear mixed models, were fitted using the generalized linear and linear mixed modeling procedures in SAS (PROC GLIMMIX and PROC MIXED, respectively; SAS, 2016). Experimental units in all analyses were the individual test plots.

Zebra mussel mortality in the containment bags was analyzed with binomial logistic regression models that used plot, treatment, and zone as categorical predictor variables. The proportion of mortalities (the number of dead compared to total number of zebra mussels in each sample) were modeled using a binomial distribution and a log odds link function.

Scale parameters were added to the models and random effects were nested within plots using the random residual and subject statements. All main effects, along with two-factor interactions were included in the logistic model fits. Post-hoc comparisons were made using two-sided least square means comparison tests. A partitioned least square means analysis was completed to explicitly compare the mortality of zebra mussels in each zone.

Zequanox concentrations, the densities of zebra mussels in the quadrat samples, water-quality parameters, and the lengths of zebra mussels in the containment bags and those in the quadrat samples were modeled using generalized linear mixed models either with a normal distribution and an identity link function or with a Poisson distribution with a log link function. Zequanox concentration, specific conductance, and turbidity data were log transformed to help normalize variance error. Sampling day was added as a covariate in the postexposure water chemistry models to allow for trends throughout time. Scale parameters were added to the models and random effects were nested within plots using the random residual and subject statements. Treatment, plot, zone, and sampling time were fixed effects in the models, as appropriate, and Zequanox concentration, zebra mussel density, water-quality parameters, and zebra mussel lengths were the response variables. All main effects, along with two- and three-factor interactions, were included in the logistic model fits. Post-hoc comparisons were made using two-sided least squared means comparison tests. Partitioned least square means analyses were used in the exposure period water chemistry and in the zebra mussel density analyses to explicitly compare the treated and control plots at each sampling time.

Fatmucket survival was analyzed with binomial logistic regression models that used site (location of plot pairs), treatment, and sampling time as categorical predictor variables. A total of 7 mussels were not recovered at 30 days postexposure and 8 mussels were not recovered at 1 year postexposure. Unrecovered mussels were omitted from survival analysis. The probability of survival was modeled with a binomial distribution. Scale parameters were added to the models and random effects were nested within plots using the random residual and subject statements. All main effects and two- or three-factor interactions were included in the logistic model fits. Least square means comparison tests were used to compare survival among sites and between treated and control plots at each sampling time.

Changes in glycogen concentration were compared using a mixed linear model that used site, treatment, and sampling time as categorical predictor variables. Glycogen analysis was completed only on samples that met the minimum sample weight required for the glycogen procedure ( 0.10 milligram) and on the mussels that survived until the postexposure sampling times. Therefore, the sample size for each test plot was less than the original number of biopsied mussels and varied among plots. Glycogen concentrations were log transformed to obtain homogeneous variances. Random effects were nested within plots with the SAS random residual and subject statements. Main effects of site, treatment, sampling time, and the interaction of treatment and sampling time were included in the model. Least square means were used to compare glycogen concentration between control and treated mussels at each sampling time.

\section{Assessment of Uncontained Zequanox Applications}

The assessment of uncontained Zequanox applications includes results of Zequanox concentrations during exposures; water-quality conditions before, during, and after exposures; density, mortality, and lengths of zebra mussels before and after exposures; and survival and condition of native mussels before and after exposures. Conclusions drawn from this assessment are summarized.

\section{Zequanox Concentration}

The concentration of Zequanox active ingredient measured in treated plots (mean $=49.9$, standard deviation $[\mathrm{SD}]=$ $29.8 \mathrm{mg} / \mathrm{L}$ ) was approximately one-half of the $100 \mathrm{mg} / \mathrm{L}$ target concentration 1 hour after application and the concentration continued to decline with time until the concentration was near background levels 8 hours after application (fig. 3). At each sampling time, zones in the treated plots were compared to like zones in the control plots. Treated plot zones had higher Zequanox concentrations through 4 hours of exposure, except for the 4-hour edge zone comparison $(t(8)=-2.08, p=0.071)$; where $t$ is the $t$-statistic, the value in parentheses is the degrees of freedom; and $p$ is the $p$-value. Differences in Zequanox concentrations were not detected in zones of the treated plots compared to like zones of the control plots 8 hours after application (control core to treated core $(t(8)=-1.24, p=0.252)$; control fringe to treated fringe $(t(8)=-1.38, p=0.206)$, 
and control edge to treated edge $(t(8)=-0.79, p=0.4549)$, indicating Zequanox dispersal or settling, or both within the treated plots. Within each treated plot, differences in Zequanox concentrations were not detected among the zones at each sampling time.

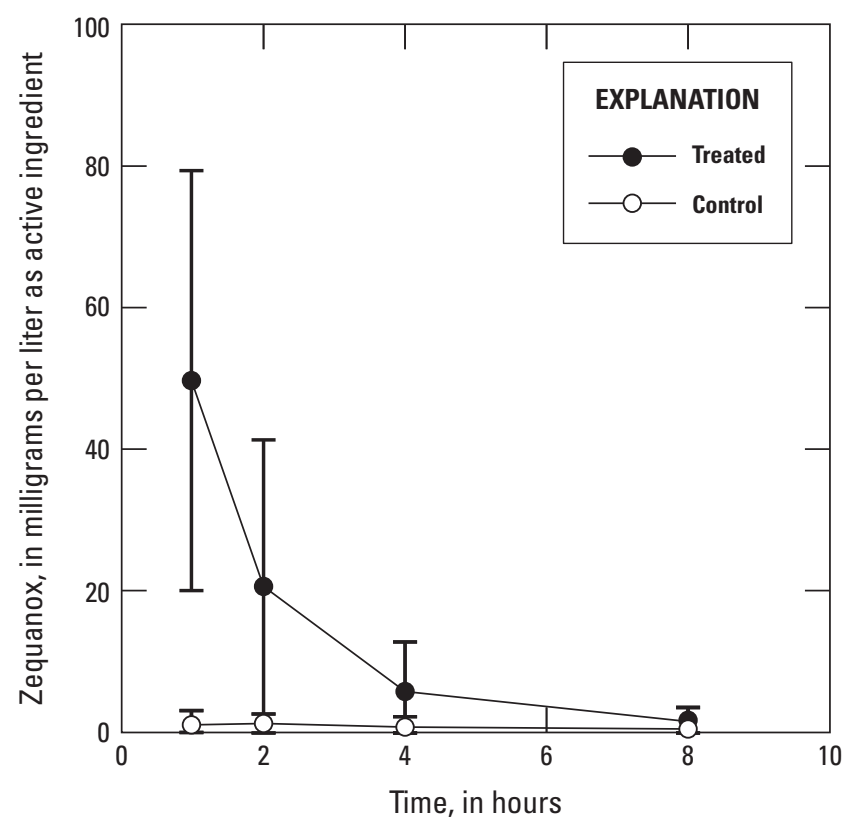

Figure 3. Mean (circles) and standard deviation (error bars) Zequanox concentrations in treated and control plots during the 8-hour uncontained Zequanox applications at Round Lake, Emmet County, Michigan.

\section{Water-Quality Conditions}

The mean and standard deviation (in parentheses) hardness and alkalinity of lake water samples collected from the core of each plot prior to treatment were 120.2 (1.2) and 110.7 (0.9) $\mathrm{mg} / \mathrm{L}$ as calcium carbonate, respectively, for the control plots, and 119.8 (1.2) and 110.1 (1.3) $\mathrm{mg} / \mathrm{L}$ as calcium carbonate, respectively, for the treated plots. Although differences in mean water-quality properties were detected between the treated and control plots during the exposure (table 1), all values were within an acceptable range to support aquatic life (Piper and others, 1982; Timmons and Ebeling, 2013). Across all plots, the range of individual water-quality properties were as follows: DO, 7.52-9.84 mg/L; $\mathrm{pH}, 7.58-8.76$ standard units; specific conductance, 249-509 microsiemens per centimeter at $25^{\circ} \mathrm{C}$; temperature, $18.3-28.1^{\circ} \mathrm{C}$; and turbidity, 2.2-109.0 nephelometric turbidity units (NTU; Luoma and others, 2019b). The mean turbidity of treated plots was 45.9 NTU higher than the mean turbidity of control plots 1 hour after application (table 1), which was indicative of the Zequanox application. Turbidity differed less than 1 NTU between control and treated plots 8 hours after application (table 1), which indicated that the Zequanox had dissipated. During the 30-day postexposure period, no differences in $\mathrm{pH}$ and temperature were detected between the control and treated plots (table 1). Differences in mean DO and specific conductance between treated and control plots were detected during the postexposure period (table 1), but individual values for all plots were within an acceptable range to support aquatic life (DO, 6.27-11.39 mg/L; pH, 7.79-8.80 standard units; specific conductance, $248-320$ microsiemens per centimeter at $25^{\circ} \mathrm{C}$; and temperature, $18.1-28.1{ }^{\circ} \mathrm{C}$; Piper and others, 1982; Timmons and Ebeling, 2013).

\section{Zebra Mussel Density}

The mean and standard deviation (in parentheses) density of live zebra mussels in each plot and zone ranged from 2.2 (4.2) to 55.8 (146.7) and from 2.0 (5.4) to 46.9 (105.5) zebra mussels per square meter in the control and treated plots, respectively (table 2). Differences in the density of zebra mussels were not detected between the treated and control plots $(t(12)=0.21, p=0.837)$. Comparison of the zebra mussel density among zones of treated and control plots, at each sampling time, detected only four combinations that were different, and two of these were control plot to control plot comparisons (control core to control fringe at 30 days postexposure $(t(12)=-2.21, p=0.042)$ and control edge to control fringe at 1 year postexposure $(t(12)=2.37, p=0.031))$. The other zone comparisons with differences were at 30 days postexposure and were the control plots fringe zones compared to treated plots core $(t(12)=2.29, p=0.036)$ and edge $(t(12)=2.41$, $p=0.028)$ zones.

\section{Zebra Mussel Mortality}

Mean and standard deviation (in parentheses) zebra mussel mortality within containment bags ranged from 3.3 (3.9) to 53.3 (48.7) percent across all zones and plots (table 3). Differences in zebra mussel mortality were not detected between treated and control plots $(t(4)=-1.32, p=0.226)$, nor did zebra mussel mortality differ among like zones of treated and control plots (treated core to control core $(t(8)=-2.00$, $p=0.081)$, treated fringe to control fringe $(t(8)=-0.85$, $p=0.421)$, and treated edge to control edge $(t(8)=0.43$, $p=0.676)$.

\section{Zebra Mussel Lengths}

The mean and standard deviation (in parentheses) length of live zebra mussels in the $0.25-\mathrm{m}^{2}$ quadrat samples from all zones, plots, and sample times ranged from 10.7 (1.9) to 23.3 (4.0) $\mathrm{mm}$ (table 4). When quadrat samples were combined by individual plot, differences in the length of live zebra mussels in the treated and control plots were not detected prior 
to exposure $(t(8)=0.61, p=0.558), 30$ days postexposure $(t(8)=1.06, p=0.3196)$, or 1 year postexposure $(t(8)=0.60$, $p=0.566)$. Furthermore, when control zones prior to exposure were compared to like treated zones at the various sampling times (for example, control core prior to exposures compared to treated core prior to exposure, 30 days postexposure, and 1 year postexposure), differences in the length of live zebra mussels in the treated zones compared to the control zones were only detected in one instance (control fringe zone prior to exposure compared to treated fringe zone 1 year postexposure $(t(16)=-2.25, p=0.039)$. The mean and standard deviation (in parentheses) length of zebra mussels in containment bags ranged from $20.59(2.45)$ to 21.06 (2.67) $\mathrm{mm}$ (Luoma and others, $2019 \mathrm{~b}$ ), and differences were not detected between the treated and control plots $(t(2)=0.02, p=0.988)$.

\section{Unionid Mussel Assessment}

Recovery of nonbiopsied mussels (group 2) used for the survival analysis was 94.9 percent at 30 days and 94.1 percent at 1 year. Survival of unionid mussels was indistinguishable among treatment and control groups $(F(1,2)=2.40$; $p=0.262$ ); where $F$ is the $F$-statistic, the values in parentheses are between groups degrees of freedom and within groups degrees of freedom, respectively, and $p$ is $p$-value (table 5), and no treatment-related effects on survival were detected between observation times $(F(1,4)=0.68, p=$ $0.465)$ or among sites $(F(2,2)=1.44 ; p=0.410)$. However, survival did vary between the 30 -day and 1 -year time points $(F(1,4)=39.0 ; p=0.003)$. Specifically, mean survival (averaged among treatments) at 30 days was nearly double that at 1 year (table 5), and differences were not detected between control and treated plots.

Table 1. Mean and standard deviation of water-quality properties measured in 2017 during the Zequanox exposure and the 30-day postexposure periods at Round Lake, Emmet County, Michigan.

[Standard deviation value is in parentheses. ${ }^{\circ} \mathrm{C}$, degrees Celsius; $\mathrm{mg} / \mathrm{L}$, milligram per liter; $\mu \mathrm{S} / \mathrm{cm}$, microsiemens per centimeter; NTU, nephelometric turbidity units; --, turbidity was not measured during the postexposure period]

\begin{tabular}{|c|c|c|c|c|c|}
\hline \multirow{2}{*}{ Property } & \multicolumn{4}{|c|}{ Exposure period (hours) } & \multirow{2}{*}{$\begin{array}{c}\text { Postexposure } \\
\text { period }\end{array}$} \\
\hline & 1 & 2 & 4 & 8 & \\
\hline \multicolumn{6}{|c|}{ Control plots } \\
\hline $\mathrm{pH}$, in standard units & $\begin{array}{c}8.58 \\
(0.08)\end{array}$ & $\begin{array}{c}8.57 \\
(0.07)\end{array}$ & $\begin{array}{c}8.64 \\
(0.10)\end{array}$ & $\begin{array}{c}8.66 \\
(0.06)\end{array}$ & $\begin{array}{c}8.51 \\
(0.19)\end{array}$ \\
\hline Dissolved oxygen, in mg/L & $\begin{array}{c}8.67 \\
(0.37)\end{array}$ & $\begin{array}{c}8.89 \\
(0.34)\end{array}$ & $\begin{array}{c}8.70 \\
(0.39)\end{array}$ & $\begin{array}{c}9.05 \\
(0.44)\end{array}$ & $\begin{array}{c}9.03 \\
(1.03)\end{array}$ \\
\hline Specific conductance, in $\mu \mathrm{S} / \mathrm{cm}$ at $25^{\circ} \mathrm{C}$ & $\begin{array}{l}280 \\
(23)\end{array}$ & $\begin{array}{l}285 \\
(3)\end{array}$ & $\begin{array}{l}276 \\
(18)\end{array}$ & $\begin{array}{l}280 \\
(25)\end{array}$ & $\begin{array}{r}292 \\
(8)\end{array}$ \\
\hline Turbidity, in NTU & $\begin{array}{c}3.7 \\
(2.2)\end{array}$ & $\begin{array}{c}4.4 \\
(1.5)\end{array}$ & $\begin{array}{c}3.6 \\
(1.6)\end{array}$ & $\begin{array}{c}3.5 \\
(1.2)\end{array}$ & -- \\
\hline Temperature, in ${ }^{\circ} \mathrm{C}$ & $\begin{array}{l}\text { a22.1 } \\
(1.4)\end{array}$ & $\begin{array}{l}\text { a23.4 } \\
(0.6)\end{array}$ & $\begin{array}{l}24.6 \\
(0.7)\end{array}$ & $\begin{array}{l}26.2 \\
(0.5)\end{array}$ & $\begin{array}{l}23.3 \\
(1.5)\end{array}$ \\
\hline $\mathrm{pH}$, in standard units & $\begin{array}{l}\text { a8.39a } \\
(0.22)\end{array}$ & $\begin{array}{c}8.53 \\
(0.19)\end{array}$ & $\begin{array}{c}8.60 \\
(0.14)\end{array}$ & $\begin{array}{c}8.62 \\
(0.14)\end{array}$ & $\begin{array}{c}8.51 \\
(0.09)\end{array}$ \\
\hline Dissolved oxygen, in mg/L & $\begin{array}{l}\text { a9.00 } \\
(0.54)\end{array}$ & $\begin{array}{c}8.79 \\
(0.44)\end{array}$ & $\begin{array}{c}8.80 \\
(0.35)\end{array}$ & $\begin{array}{l}\text { a } 8.77 \\
(0.26)\end{array}$ & $\begin{array}{l}\text { a9.47 } \\
(0.72)\end{array}$ \\
\hline Specific conductance, in $\mu \mathrm{S} / \mathrm{cm}$ at $25^{\circ} \mathrm{C}$ & $\begin{array}{l}289 \\
(23)\end{array}$ & $\begin{array}{l}280 \\
(16)\end{array}$ & $\begin{array}{l}281 \\
(28)\end{array}$ & $\begin{array}{l}286 \\
(48)\end{array}$ & $\begin{array}{l}296 \\
(6)\end{array}$ \\
\hline Turbidity, in NTU & $\begin{array}{l}\text { a } 49.6 \\
(30.5)\end{array}$ & $\begin{array}{l}\text { a21.9 } \\
(21.0)\end{array}$ & $\begin{array}{l}{ }^{\mathrm{a}} 8.2 \\
(7.0)\end{array}$ & $\begin{array}{c}4.2 \\
(1.8)\end{array}$ & -- \\
\hline
\end{tabular}

avalue is different than corresponding control value within the same column. 
Mean growth of fatmuckets at 1 year was minimal and, in some cases, shell length or width decreased (table 6).

The mean and standard deviation (in parentheses) number of attached zebra mussels prior to exposure, 30 days postexposure, and 1 year postexposure ranged from 2.2 (3.4) to 3.5 (5.3), 1.4 (3.4) to 3.0 (5.0), and 1.0 (2.9) to 2.2 (4.1), respectively, and no differences were detected between treated and control plots 30 days or 1 year postexposure (Luoma and others, 2019b).

Reagent blank samples used to assess reagent purity and procedural contamination during the glycogen analyses indicated negligible procedural contamination. Glycogen content in fatmucket tissue samples was greater in mussels prior to Zequanox exposure compared to both postexposure sampling times (table $7 ; F(2,98)=39.3, p<0.001)$. Mean and standard deviation (in parentheses) glycogen concentration in tissue samples from mussels in the control and treated plots before application was 104.4 (65.0) and 87.1 (61.1) micrograms per milligram, respectively (table 7 ). The results indicate no obvious effect of Zequanox treatment on glycogen content 30 days postexposure, and low survival of biopsied native mussels 1 year postexposure precluded robust comparisons of muscle glycogen content.

Table 2. Mean and standard deviation density of live zebra mussels (expressed as number per square meter) in treatment plots before and after Zequanox exposure at Round Lake, Emmet County, Michigan.

[Standard deviation value is in parentheses]

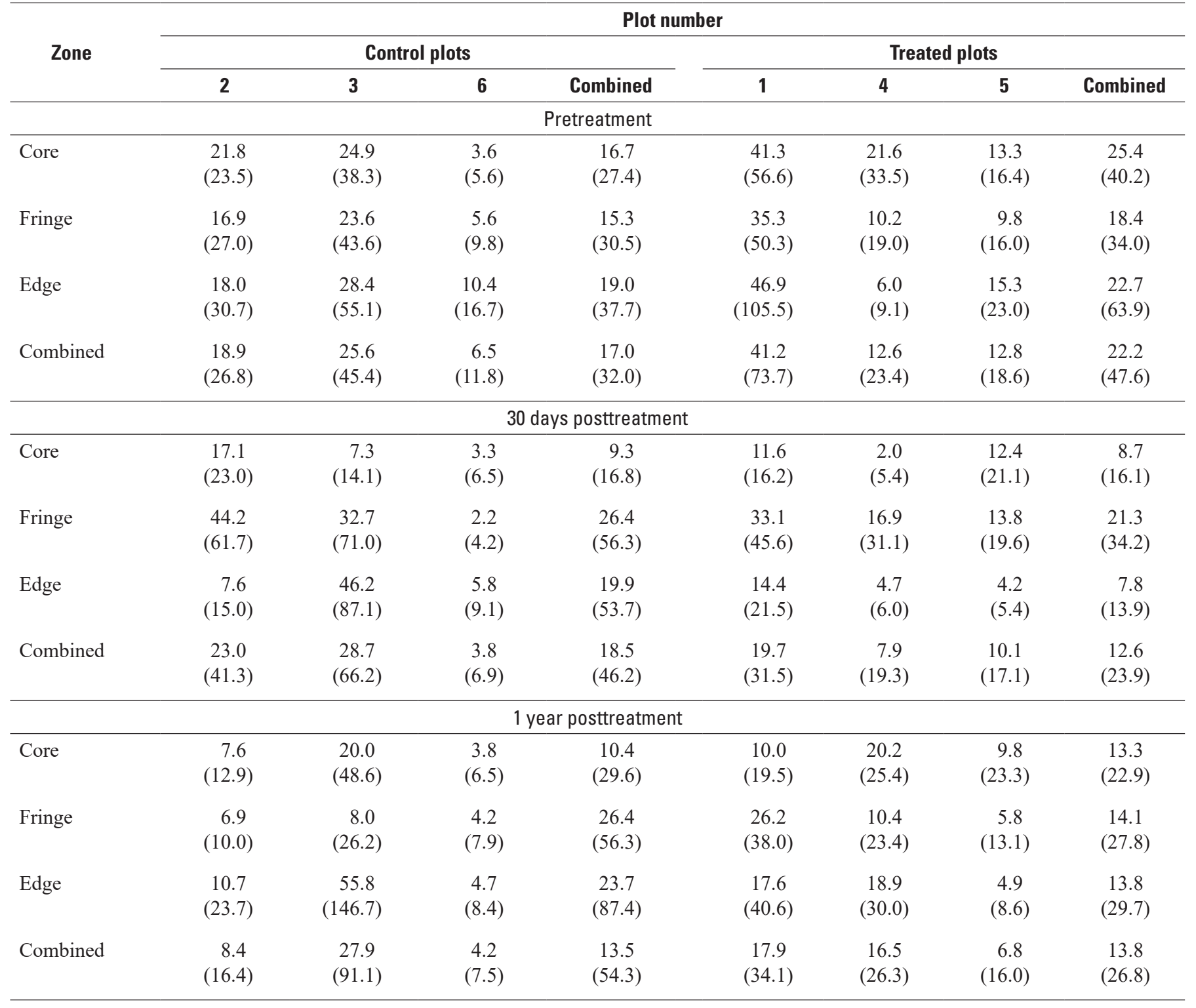


12 Assessment of Uncontained Zequanox Applications for Zebra Mussel Control in a Midwestern Lake

Table 3. Mean and standard deviation percent mortality of caged zebra mussels that were exposed during uncontained Zequanox applications at Round Lake, Emmet County, Michigan.

[Standard deviation value is in parentheses]

\begin{tabular}{|c|c|c|c|c|}
\hline \multirow{2}{*}{ Plot } & \multicolumn{4}{|c|}{ Plot zone } \\
\hline & Core & Fringe & Edge & Combined \\
\hline \multicolumn{5}{|c|}{ Control plots } \\
\hline 2 & $\begin{array}{c}20.7 \\
(39.3)\end{array}$ & $\begin{array}{c}9.7 \\
(5.5)\end{array}$ & $\begin{array}{c}29.3 \\
(39.4)\end{array}$ & $\begin{array}{c}19.9 \\
(31.4)\end{array}$ \\
\hline 3 & $\begin{array}{c}3.3 \\
(3.9)\end{array}$ & $\begin{array}{c}37.5 \\
(45.8)\end{array}$ & $\begin{array}{c}38.7 \\
(45.5)\end{array}$ & $\begin{array}{c}26.5 \\
(38.9)\end{array}$ \\
\hline 6 & $\begin{array}{c}9.4 \\
(8.4)\end{array}$ & $\begin{array}{c}9.3 \\
(7.0)\end{array}$ & $\begin{array}{c}6.7 \\
(4.1)\end{array}$ & $\begin{array}{c}8.5 \\
(6.5)\end{array}$ \\
\hline Combined & $\begin{array}{c}11.1 \\
(23.1)\end{array}$ & $\begin{array}{c}18.8 \\
(28.7)\end{array}$ & $\begin{array}{c}24.9 \\
(35.5)\end{array}$ & $\begin{array}{c}18.3 \\
(29.5)\end{array}$ \\
\hline \multicolumn{5}{|c|}{ Treated plots } \\
\hline 1 & $\begin{array}{c}41.8 \\
(29.3)\end{array}$ & $\begin{array}{c}48.7 \\
(44.9)\end{array}$ & $\begin{array}{c}28.2 \\
(35.5)\end{array}$ & $\begin{array}{c}39.6 \\
(35.9)\end{array}$ \\
\hline 4 & $\begin{array}{c}53.3 \\
(48.7)\end{array}$ & $\begin{array}{c}21.3 \\
(32.8)\end{array}$ & $\begin{array}{c}18.7 \\
(36.0)\end{array}$ & $\begin{array}{c}31.1 \\
(40.7)\end{array}$ \\
\hline 5 & $\begin{array}{c}9.3 \\
(8.6)\end{array}$ & $\begin{array}{l}10.7 \\
(6.0)\end{array}$ & $\begin{array}{c}13.3 \\
(11.8)\end{array}$ & $\begin{array}{l}11.1 \\
(8.7)\end{array}$ \\
\hline Combined & $\begin{array}{c}34.8 \\
(36.6)\end{array}$ & $\begin{array}{c}26.9 \\
(34.5)\end{array}$ & $\begin{array}{c}20.1 \\
(28.8)\end{array}$ & $\begin{array}{c}27.3 \\
(33.4)\end{array}$ \\
\hline
\end{tabular}


Table 4. Mean and standard deviation shell length (in millimeters) of live zebra mussels in quadrat samples from zones of Zequanoxtreated and control plots at Round Lake, Emmet County, Michigan.

[Standard deviation value is in parentheses]

\begin{tabular}{|c|c|c|c|c|c|c|c|c|}
\hline \multirow{3}{*}{ Zone } & \multicolumn{8}{|c|}{ Plot number } \\
\hline & \multicolumn{4}{|c|}{ Control plots } & \multicolumn{4}{|c|}{ Treated plots } \\
\hline & 2 & 3 & 6 & Combined & 1 & 4 & 5 & Combined \\
\hline Core & $\begin{array}{l}14.9 \\
(5.6)\end{array}$ & $\begin{array}{c}15.2 \\
(6.3)\end{array}$ & $\begin{array}{c}22.3 \\
(3.8)\end{array}$ & $\begin{array}{c}16.0 \\
(6.2)\end{array}$ & $\begin{array}{l}16.1 \\
(6.4)\end{array}$ & $\begin{array}{l}14.9 \\
(5.7)\end{array}$ & $\begin{array}{c}17.1 \\
(6.3)\end{array}$ & $\begin{array}{l}15.9 \\
(6.2)\end{array}$ \\
\hline Edge & $\begin{array}{c}15.0 \\
(6.0)\end{array}$ & $\begin{array}{c}14.2 \\
(5.4)\end{array}$ & $\begin{array}{c}18.3 \\
(5.8)\end{array}$ & $\begin{array}{l}15.6 \\
(5.9)\end{array}$ & $\begin{array}{c}14.4 \\
(6.1)\end{array}$ & $\begin{array}{l}18.1 \\
(5.0)\end{array}$ & $\begin{array}{l}15.9 \\
(6.1)\end{array}$ & $\begin{array}{c}15.8 \\
(6.0)\end{array}$ \\
\hline Combined & $\begin{array}{l}14.9 \\
(5.9)\end{array}$ & $\begin{array}{l}14.8 \\
(6.0)\end{array}$ & $\begin{array}{c}20.1 \\
(5.2)\end{array}$ & $\begin{array}{c}15.9 \\
(6.2)\end{array}$ & $\begin{array}{c}15.3 \\
(6.2)\end{array}$ & $\begin{array}{l}15.1 \\
(5.7)\end{array}$ & $\begin{array}{c}16.8 \\
(6.1)\end{array}$ & $\begin{array}{l}15.7 \\
(6.1)\end{array}$ \\
\hline Fringe & $\begin{array}{l}15.3 \\
(5.9)\end{array}$ & $\begin{array}{c}14.3 \\
(5.2)\end{array}$ & $\begin{array}{l}19.8 \\
(4.5)\end{array}$ & $\begin{array}{l}15.3 \\
(5.6)\end{array}$ & $\begin{array}{l}15.7 \\
(6.1)\end{array}$ & $\begin{array}{c}14.8 \\
(4.8)\end{array}$ & $\begin{array}{c}18.8 \\
(4.8)\end{array}$ & $\begin{array}{l}16.2 \\
(5.6)\end{array}$ \\
\hline Edge & $\begin{array}{c}18.0 \\
(5.2)\end{array}$ & $\begin{array}{l}14.0 \\
(5.2)\end{array}$ & $\begin{array}{c}18.0 \\
(5.6)\end{array}$ & $\begin{array}{l}16.1 \\
(5.6)\end{array}$ & $\begin{array}{l}14.5 \\
(5.2)\end{array}$ & $\begin{array}{l}12.0 \\
(4.1)\end{array}$ & $\begin{array}{l}19.1 \\
(5.4)\end{array}$ & $\begin{array}{c}14.5 \\
(5.5)\end{array}$ \\
\hline Combined & $\begin{array}{c}16.0 \\
(5.8)\end{array}$ & $\begin{array}{l}14.5 \\
(5.3)\end{array}$ & $\begin{array}{l}18.5 \\
(5.3)\end{array}$ & $\begin{array}{c}15.8 \\
(5.7)\end{array}$ & $\begin{array}{l}14.9 \\
(5.5)\end{array}$ & $\begin{array}{c}13.2 \\
(4.6)\end{array}$ & $\begin{array}{c}18.2 \\
(5.4)\end{array}$ & $\begin{array}{c}15.4 \\
(5.6)\end{array}$ \\
\hline \multicolumn{9}{|c|}{1 year posttreatment } \\
\hline Core & $\begin{array}{c}16.4 \\
(3.5)\end{array}$ & $\begin{array}{c}14.0 \\
(5.0)\end{array}$ & $\begin{array}{c}23.3 \\
(4.0)\end{array}$ & $\begin{array}{c}16.5 \\
(5.6)\end{array}$ & $\begin{array}{c}18.7 \\
(4.2)\end{array}$ & $\begin{array}{c}13.7 \\
(4.0)\end{array}$ & $\begin{array}{c}19.9 \\
(3.6)\end{array}$ & $\begin{array}{c}16.6 \\
(4.8)\end{array}$ \\
\hline
\end{tabular}


Table 5. Mean and standard deviation percent survival of nonbiopsied native fatmuckets, by treatment, that were exposed during uncontained Zequanox applications at Round Lake, Emmet County, Michigan.

[Standard deviation values are in parentheses. Number of mussels placed was 24 mussels per plot in plots 1-4 and 20 mussels per plot in plots 5-6. The number of mussels recovered at the posttreatment sampling time are in brackets]

\begin{tabular}{|c|c|c|c|c|c|c|c|}
\hline \multicolumn{8}{|c|}{ Plot number } \\
\hline \multicolumn{4}{|c|}{ Control plots } & \multicolumn{4}{|c|}{ Treated plots } \\
\hline 2 & 3 & 6 & Combined & 1 & 4 & 5 & Combined \\
\hline \multicolumn{8}{|c|}{30 days posttreatment } \\
\hline 95.5 & 91.3 & 95.0 & 93.8 & 95.8 & 80.0 & 100.0 & 92.2 \\
\hline$(21.3)$ & $(28.9)$ & $(21.1)$ & $(24.3)$ & $(20.4)$ & $(41.0)$ & $(0.0)$ & $(27.0)$ \\
\hline$[22]$ & {$[23]$} & {$[20]$} & {$[65]$} & {$[24]$} & {$[20]$} & {$[20]$} & {$[64]$} \\
\hline \multicolumn{8}{|c|}{1 year posttreatment } \\
\hline 65.2 & 60.9 & 70.0 & 65.2 & 50.0 & 38.9 & 42.3 & 44.1 \\
\hline$(48.7)$ & (49.9) & $(47.0)$ & $(48.0)$ & $(51.1)$ & $(50.2)$ & $(50.4)$ & $(50.0)$ \\
\hline$[23]$ & {$[23]$} & {$[20]$} & {$[66]$} & [24] & {$[18]$} & {$[20]$} & [62] \\
\hline
\end{tabular}

Table 6. Mean and standard deviation initial shell length, width, and height (in millimeters) of native fatmuckets and change in shell dimensions 1 year after Zequanox exposure at Round Lake, Emmet County, Michigan.

[Standard deviation value is in parentheses. Sample size was 68 mussels per plot in plots $1-4$ and 64 per plot in plots 5-6]

\begin{tabular}{lcccccc}
\hline \multirow{2}{*}{ Shell dimension } & \multicolumn{7}{c}{ Plot number } \\
\cline { 2 - 7 } & \multicolumn{3}{c}{ Control plots } & $\mathbf{1}$ & Treated plots \\
\cline { 2 - 7 } & $\mathbf{2}$ & $\mathbf{3}$ & $\mathbf{6}$ & $\mathbf{1}$ & $\mathbf{4}$ & $\mathbf{5}$ \\
\hline Initial length & 64.4 & 65.5 & 65.4 & 64.1 & 65.3 & 64.8 \\
& $(7.3)$ & $(6.5)$ & $(7.6)$ & $(6.6)$ & $(7.5)$ & $(7.4)$ \\
Change in length & 0.1 & -0.1 & 0.0 & 0.2 & -0.2 & -0.3 \\
& $(0.6)$ & $(0.7)$ & $(0.8)$ & $(0.7)$ & $(0.6)$ & $(1.2)$ \\
Initial width & 22.4 & 23.0 & 22.8 & 22.6 & 23.5 & 22.8 \\
& $(2.8)$ & $(3.0)$ & $(3.2)$ & $(2.5)$ & $(5.0)$ & $(2.6)$ \\
Change in width & -0.3 & 0.1 & 0.1 & 0.2 & 0.3 & 0.0 \\
Initial height & $(0.8)$ & $(0.7)$ & $(1.0)$ & $(0.6)$ & $(0.8)$ & $(0.8)$ \\
& 38.1 & 38.6 & 39.0 & 38.8 & 39.0 & 38.8 \\
Change in height & $(3.7)$ & $(4.2)$ & $(4.1)$ & $(3.4)$ & $(4.2)$ & $(3.5)$ \\
& -0.2 & 0.3 & 0.4 & 0.6 & -0.2 & 1.0 \\
& $(0.9)$ & $(1.4)$ & $(1.3)$ & $(1.0)$ & $(0.6)$ & $(0.8)$ \\
\hline
\end{tabular}


Table 7. Mean and standard deviation glycogen concentration (micrograms per milligram) in foot tissue samples of fatmuckets that were exposed to Zequanox during uncontained Zequanox applications at Round Lake, Emmet County, Michigan.

[Standard deviation value is in parentheses. Sample size is in brackets. --, incalculable]

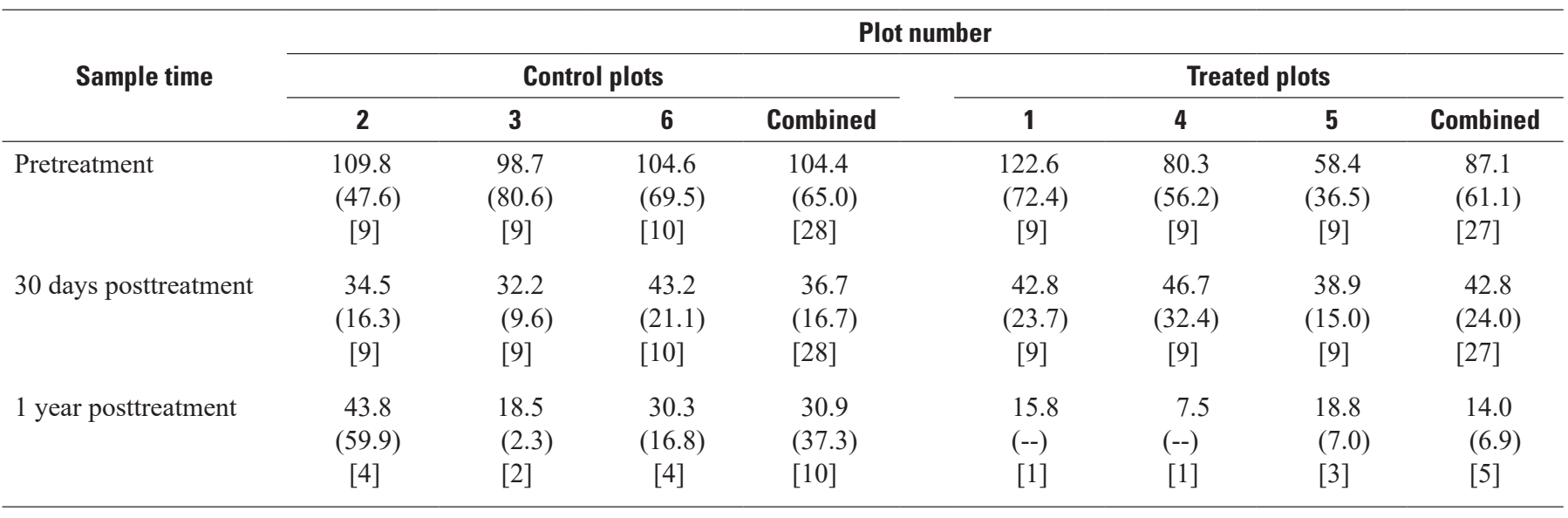

\section{Assessment Conclusions}

The concentrations of Zequanox suspensions were selected based on the results of previous work (Severson and Luoma, 2016). The application system was specifically engineered for this study and applications were completed during calm weather conditions to maximize the potential for a persistent and stratified benthic layer of Zequanox in the treated plots. However, visual observations of the treated plots during and shortly after application indicated that Zequanox rapidly diffused horizontally and vertically. Observations were confirmed by measured Zequanox concentrations (fig. 3). In a similar study during which subsurface Zequanox applications of the same concentration were completed within barriers, Zequanox concentrations $15 \mathrm{~cm}$ above the sediment-water interface were approximately 70 percent of target 4 hours after application and 45 percent of target 8 hours after application (Luoma and Severson, 2016). Without barriers to contain the Zequanox in the treatment area, results indicated that samples collected 1 hour after application had similar concentrations as samples collected 8 hours after application in the barrier study. Additionally, samples collected 4 hours after application had Zequanox concentrations that were more than 7 times lower than the concentrations reported 8 hours after application in the same barriered-application study. The rapid dissipation of Zequanox from the treated plots resulted in concentrations that were insufficient to produce appreciable zebra mussel mortality. Although the mean mortality of caged zebra mussels in the Zequanox-treated plots was higher than corresponding control plots, treatment-related differences were not detected. Anecdotal observations during this study indicate that poor habitat, primarily related to the soft substrates within the plots, may have affected test animal survival. Mortality was lowest in plots 5 and 6 , where the substrate was noticeably firmer relative to the soft and flocculant substrate observed in plots 1-4.
The densities (table 2) and mean shell lengths (table 4) of zebra mussels in the Zequanox-treated and control plots measured before application, 30 days posttreatment, and 1 year posttreatment were variable, but no differences were observed at any of the sampling times. Zebra mussel colonization of fatmuckets in each plot was low before treatment (mean $=2.2$ to 3.5 zebra mussels per native mussel) and results indicated no appreciable reduction in the number of attached zebra mussels at 30 days or 1 year posttreatment. Results indicated an overall reduction in mean number of attached zebra mussels 1 year posttreatment, which may be attributed to incidental detachment of mussels during the handling of the fatmuckets.

Survival of fatmuckets 30 days postexposure was 80 percent or greater in all plots, indicating that Zequanox treatment did not affect 30-day survival. Survival 1 year posttreatment was appreciably lower than at 30 days posttreatment in all plots (table 5). Most dead mussels collected at 1 year had no soft tissue, the shell nacre was chalky, and periostracum was brittle - all signs that mortality occurred several months prior to collection. Additionally, many dead mussels were in clusters near the substrate surface indicating that the mussels had not repositioned and buried properly after being returned from the 30-day assessment. The mortality after 30 days among all mussel groups may be attributed to accumulated stress related to handling and poor substrate quality.

Glycogen is the main energy storage molecule in freshwater mussels, and glycogen has been previously used as a measure of body condition (Patterson and others, 1999; Fritts and others, 2015). Starvation (Patterson and others, 1997) and zebra mussel biofouling (Haag and others, 1993) have been determined to cause decreases in the glycogen reserves of native freshwater mussels. In this study, the baseline glycogen content of fatmuckets before Zequanox application (table 7) was indicative of healthy mussels in suitable habitat (Fritts and others, 2015). Mean glycogen was lower 30 days after 
treatment in the Zequanox-treated and control groups. The observed decline in glycogen content may be attributed to seasonal effects or a decrease in available food resources; however, stress related to handling, relocation, and habitat changes likely contributed to the decreases in glycogen content (Haag and others, 1993; Patterson and others, 1999; Fritts and others, 2015). Mussels that survived to 1 year did not maintain or increase glycogen stores, but rather glycogen content generally declined below levels measured 30 days after treatment (table 7). The further decline in glycogen content indicates that the habitat of each plot may have been inferior than the original collection site.

Zequanox application has been documented to increase water turbidity and contained applications that exceed 12 hours in duration are likely to decrease DO concentrations (Luoma and others, 2015c; Whitledge and others, 2015; Lund and others, 2018). In this study, turbidity measurements 1 hour after application were more that 13 times higher in the treated plots compared to the control plots (table 1). However, turbidity in treated plots concomitantly decreased with Zequanox concentrations with time and results indicated no difference between the treated and control plots 8 hours after application. Throughout the exposure and postexposure periods, all water-quality properties were within acceptable ranges to support aquatic life (Piper and others, 1982; Timmons and Ebeling, 2013).

This study was completed to evaluate the potential for using uncontained Zequanox applications for the management of dreissenid mussels in surface waters. A concentrated Zequanox suspension was applied with a custom-engineered application system to achieve the target concentration of $100 \mathrm{mg} / \mathrm{L}$ of Zequanox active ingredient in the bottom $0.75 \mathrm{~m}$ of the water column. Applications were applied during calm weather conditions to decrease dissipation of Zequanox from the treatment plot. Despite these steps, effective Zequanox concentrations were unable to be maintained for the required exposure duration. Results of this study indicate that Zequanox requires containment within a barrier system when applied to surface waters for the management of dreissenid mussels. If improved formulations of Zequanox are developed that can reduce the required exposure time or alter the delivery methods by utilizing a granular or similar slow-release formulation, then further investigation may be warranted.

\section{References Cited}

Adlerstein, S., Nalepa, T.F., Vanderploeg, H.A., and Fahnenstiel, G.L., 2013, Trends in phytoplankton, zooplankton, and macroinvertebrates in Saginaw Bay relative to zebra mussel (Dreissena polymorpha) colonization-A general linear model approach, in Nalepa, T.F., and Schloesser, D.W., eds., Quagga and zebra mussels - Biology, impacts, and control (2d ed.): Boca Raton, Fla., CRC Press, Taylor \& Francis Group, p. 525-544, https://doi.org/10.1201/b15437.
American Public Health Association, 2012, Standard methods for the examination of water and wastewater ( $22 \mathrm{~d}$ ed.): Washington, D.C., American Public Health Association, $1,348 \mathrm{p}$.

Benson, A.J., Raikow, D., Larson, J., Fusaro, A., and Bogdanoff, A.K., 2019, Dreissena polymorpha (Pallas, 1771): U.S. Geological Survey, Nonindigenous Aquatic Species Database, Gainesville, FL, accessed September 30, 2019, at https://nas.er.usgs.gov/queries/FactSheet.aspx?speciesID=5, Revision Date: 9/13/2019.

Birnbaum, C., 2011, NOBANIS—Invasive alien species fact sheet-Dreissena polymorpha: Online database of the European Network on Invasive Alien Species: accessed December 17, 2018, at https://www.nobanis.org/ globalassets/speciesinfo/d/dreissena-polymorpha/dreissena polymorpha.pdf.

Brady, T.R., Aloisi, D., Gordon, D, and Wege G., 2010, A method for culturing mussels using in-river cages: Journal of Fish and Wildlife Management, v. 2, no. 1, p. 85-89.

Bruesewitz, D.A., 2008, The effects of invasive zebra mussels (Dreissena polymorpha) on nitrogen cycling in freshwater ecosystems of the Midwestern United States: Notre Dame, Ind. University of Notre Dame, Ph.D. thesis, 257 p.

Chakraborti, R.K., Madon, S., Kaur, J., and Gabel, D., 2013, Management and control of dreissenid mussels in water infrastructure facilities of the Southwestern United States, in Nalepa, T.F., and Schloesser D.W. eds., Quagga and zebra mussels-Biology, impacts, and control (2d ed.): Boca Raton, Fla., CRC Press, Taylor \& Francis Group, p. 215-242.

Colvin, M.E., Pierce, C.L., and Stewart, T.W., 2015, A food web modeling analysis of a midwestern, USA eutrophic lake dominated by non-native common carp and zebra mussels: Ecological Modelling, v. 312, p. 26-40, https://doi.org/10.1016/j.ecolmodel.2015.05.016.

De Leon, R., 2008, Testimony before the U.S. House of Representatives Committee on natural resources subcommittee on water and power, June 24, 2008-The silent invasion-Finding solutions to minimize the impacts of invasive quagga mussels on water rates, water infrastructure and the environment: accessed October 31,2019, at https://www.usbr.gov/lc/region/programs/quagga/testimony/ MWD.pdf.

Dojlido, J., Zbieć, E., and Ŝwietlik, R., 1999, Formation of the haloacetic acids during ozonation and chlorination of water in Warsaw waterworks (Poland): Water Research, v. 33, no. 14, p. 3111-3118, accessed September 27, 2019, at https://doi.org/10.1016/S0043-1354(99)00030-5. 
Fritts, A.K., Peterson, J.T., Hazelton, P.D., and Bringolf, R.B., 2015, Evaluation of methods for assessing physiological biomarkers of stress in freshwater mussels: Canadian Journal of Fisheries and Aquatic Sciences, v. 72, no. 10, p. 1450-1459, https://doi.org/10.1139/cjfas-2014-0564.

Haag, W.R., Berg, D.J., Garton, D.W., and Farris, J.L., 1993, Reduced survival and fitness in native bivalves in response to fouling by the introduced zebra mussel (Dreissena polymorpha) in western Lake Erie: Canadian Journal of Fisheries and Aquatic Sciences, v. 50, no. 1, p. 13-19, https://doi.org/10.1139/f93-002.

Hoyle, J.A., Bowlby, J.N., and Morrison, B.J., 2008, Lake whitefish and walleye population responses to dreissenid mussel invasion in eastern Lake Ontario: Aquatic Ecosystem Health \& Management, v. 11, no. 4, p. 403-411, https://doi.org/10.1080/14634980802530392.

Knoll, L.B., Sarnelle, O., Hamilton, S.K., Kissman, C.E., Wilson, A.E., Rose, J.B., and Morgan, M.R., 2008, Invasive zebra mussels (Dreissena polymorpha) increase cyanobacterial toxin concentrations in low-nutrient lakes: Canadian Journal of Fisheries and Aquatic Sciences, v. 65, no. 3, p. 448-455, https://doi.org/10.1139/f07-181.

Lake-Link, Inc., 2019, Michigan Lakes-Round Lake, Emmet County, Michigan: Lake-Link, Inc. web page, accessed September 27, 2019, at https://www.lake-link.com/michiganlakes/emmet-county/round-lake/22262/.

Lewandowski, K., and Stańczykowska, A., 2014, Summary of zebra mussel (Dreissena polymorpha) in polish lakes over the past 50 years in eastern Europe with notes on size structure of populations, in Nalepa, T.F., and Schloesser D.W., eds., Quagga and zebra mussels-Biology, impacts, and control (2d ed.): Boca Raton, Fla., CRC Press, Taylor \& Francis Group, p. 103-112.

Lund, K., Cattoor, K.B., Fieldseth, E., Sweet, J., and McCartney, M.A., 2018, Zebra mussel (Dreissena polymorpha) eradication efforts in Christmas Lake, Minnesota: Lake and Reservoir Management, v. 34, no. 1, p. 7-20, https://doi.org/10.1080/10402381.2017.1360417.

Luoma, J.A., and Severson, T.J., 2016, Efficacy of spray-dried Pseudomonas fluorescens, strain CL145A (Zequanox ${ }^{\circledR}$ ), for controlling zebra mussels (Dreissena polymorpha) within Lake Minnetonka, MN Enclosures: Legislative-Citizen Commission on Minnesota Resources, U.S. Geological Survey Cooperator Project Completion Report, 20 p., accessed September 27, 2019 at https://www.lccmr.leg.mn/ projects/2013/finals/2013_06f_attachment_6.pdf.

Luoma, J.A., Severson, T.J., Weber, K.L., and Mayer, D.A., 2015a, Efficacy of Pseudomonas fluorescens (Pf-CL145A) spray dried powder for controlling zebra mussels adhering to test substrates: U.S. Geological Survey Open-File Report 2015-1050, 519 p., https://doi.org/10.3133/ofr20151050.
Luoma, J.A., and Waller, D.L. 2019a, Assessment of uncontained Zequanox applications in a Midwestern lake code. U.S. Geological Survey code release, https://doi.org/10.5066/P90JY18D.

Luoma, J.A., Waller, D.L., Severson, T.J., Barbour, M.T., Wise, J.K., Lord, E.G., Bartsch, L.A., Bartsch, M.R., 2019b, Assessment of uncontained Zequanox applications in a Midwestern lake data: U.S. Geological Survey data release, https://doi.org/10.5066/P9ZPKI64.

Luoma, J.A., Weber, K.L., Severson, T.J., and Mayer, D.A., 2015b, Efficacy of Pseudomonas fluorescens strain CL145A spray dried powder for controlling zebra mussels adhering to native unionid mussels within field enclosures: U.S. Geological Survey Open-File Report 2015-1051, 301 p., https://doi.org/10.3133/ofr20151051.

Luoma, J.A., Weber, K.L., Waller, D.L., Wise, J.K., Mayer, D.A., and Aloisi, D.B., 2015c, Safety of spray-dried powder formulated Pseudomonas fluorescens strain CL145A exposure to subadult/adult unionid mussels during simulated open-water treatments: U.S. Geological Survey Open-File Report 2015-1064, 248 p., https://dx.doi.org/10.3133/ ofr20151064.

Mackie, G.L., and Claudi, R., 2010, Monitoring and control of macrofouling mollusks in freshwater systems ( $2 \mathrm{~d}$ ed.): Boca Raton, Fla., CRC Press, Taylor \& Francis Group, 508 p.

Marrone Bio Innovations, 2019, Zequanox Pesticide Label: accessed September 27, 2019, at https://marronebio.com/ download/zequanox-label/.

Mayer, D.A., 2011, Evaluation of a biopesticide against invasive species for native species restoration, State University of New York at Albany, Ph. D. thesis, 102 p.

Molloy, D.P., 1998, The potential for using biological control technologies in the management of Dreissena spp: Journal of Shellfish Research, v. 17, no. 1, p. 177-183.

Molloy, D.P., Mayer, D.A., Gaylo, M.J., Burlakova, L.E., Karatayev, A.Y., Presti, K.T., Sawyko, P.M., Morse, J.T., and Paul, E., 2013a, Non-target trials with Pseudomonas fluorescens strain CL145A, a lethal control agent of dreissenid mussels (Bivalvia—Dreissenidae): Management of Biological Invasions, v. 4, no. 1, p. 71-79, https://doi. org/10.3391/mbi.2013.4.1.09.

Molloy, D.P., Mayer, D.A., Gaylo, M.J., Morse, J.T., Presti, K.T., Sawyko, P.M., Karatayev, A.Y., Burlakova, L.E., Laruelle, F., Nishikawa, K.C., and Griffin, B.H., 2013b, Pseudomonas fluorescens strain CL145A-A biopesticide for the control of zebra and quagga mussels (BivalviaDreissenidae): Journal of Invertebrate Pathology, v. 113, no. 1, p. 104-114, https://doi.org/10.1016/j.jip.2012.12.012. 
Nokes, C.J., Fenton, E., and Randall, C.J., 1999, Modelling the formation of brominated trihalomethanes in chlorinated drinking waters: Water Research, v. 33, no. 17, p. 35573568, https://doi.org/10.1016/S0043-1354(99)00081-0.

Orlova, M.I., 2014, Origin and spread of quagga mussels (Dreissena rostriformis bugensis) in eastern Europe with notes on size structure of populations, in Nalepa, T.F., and Schloesser D.W., eds., Quagga and zebra mussels: biology, impacts, and control (2d ed.): Boca Raton, Fla., CRC Press, Taylor \& Francis Group, p. 93-102.

Orlova, M., Golubkov, S., Kalinina, L., and Ignatieva, N., 2004, Dreissena polymorpha (Bivalvia-Dreissenidae) in the Neva Estuary (eastern Gulf of Finland, Baltic Sea) - Is it a biofilter or source for pollution?: Marine Pollution Bulletin, v. 49, no. 3, p. 196-205, https://doi.org/10.1016/j.marpolbul.2004.02.008.

Patterson, M.A., Parker, B.C., and Neves, R.J., 1997, Effects of quarantine times on glycogen levels of native freshwater mussels (Bivalvia-Unionidae) previously infested with zebra mussels: American Malacological Bulletin, v. 14, p. $75-80$.

Patterson, M.A., Parker, B.C., and Neves, R.J., 1999, Glycogen concentration in the mantle tissue of freshwater mussels (Bivalvia-Unionidae) during starvation and controlled feeding: American Malacological Bulletin, v. 15, p. 47-50.

Piper, R.G., Mc Elwain, I.B., Orrne, L.E., McCraren, J.P., Fowler, L.G., and Leonard, J.R., 1982, Fish hatchery management: Washington, D.C., U.S. Department of the Interior, U.S. Fish \& Wildlife Service, 517 p.

Ricciardi, A., Neves, R.J., and Rasmussen, J.B., 1998, Impending extinctions of North American freshwater mussels (Unionoida) following the zebra mussel (Dreissena polymorpha) invasion: Journal of Animal Ecology, v. 67 , no. 4, p. 613-619, https://doi.org/10.1046/j.13652656.1998.00220.x.

Richardson, S.D., Plewa, M.J., Wagner, E.D., Schoeny, R., and DeMarini, D.M., 2007, Occurrence, genotoxicity, and carcinogenicity of regulated and emerging disinfection by-products in drinking water-A review and roadmap for research: Mutation Research/Reviews in Mutation Research, v. 636, no. 1-3, p. 178-242, https://doi.org/10.1016/j.mrrev.2007.09.001.

SAS, 2016, Version 9.4: Cary, N.C., SAS Institute Inc.

Severson, T.J., and Luoma, J.A., 2016, Development of targeted delivery techniques for Zequanox ${ }^{\circledR}$ : U.S. Geological Survey Cooperator Project Completion Report, 14 p., accessed September 27, 2019, at https://www.lccmr.leg.mn/ projects/2013/finals/2013_06f_attachment_5.pdf.
Sousa, R., Novais, A., Costa, R., and Strayer, D.L., 2014, Invasive bivalves in fresh waters - Impacts from individuals to ecosystems and possible control strategies: Hydrobiologia, v. 735, no. 1, p. 233-251, https://doi.org/10.1007/ s10750-012-1409-1.

Strayer, D.L., Hattala, K.A., and Kahnle, A.W., 2004, Effects of an invasive bivalve (Dreissena polymorpha) on fish in the Hudson River estuary: Canadian Journal of Fisheries and Aquatic Sciences, v. 61, p. 924-941, https://doi.org/10.1139/f04-043.

Strayer, D.L., and Malcom, H.M., 2007, Effects of zebra mussels (Dreissena polymorpha) on native bivalvesThe beginning of the end or the end of the beginning?: Journal of the North American Benthological Society, v. 26, no. 1, p. 111-122, https://doi.org/10.1899/08873593(2007)26[111:EOZMDP]2.0.CO;2.

Timmons, M.B., and Ebeling, J.M., eds., 2013, Recirculating aquaculture ( $3 \mathrm{~d}$ ed.): Ithaca, N.Y., Cayuga Aqua Ventures, Northeastern Regional Aquaculture Center publication No. 401-2013, 788 p.

Vanderploeg, H.A., Liebig, J.R., Carmichael, W.W., Agy, M.A., Johengen, T.H., Fahnenstiel, G.L., and Nalepa, T.F., 2001, Zebra mussel (Dreissena polymorpha) selective filtration promoted toxic Microcystis blooms in Saginaw Bay (Lake Huron) and Lake Erie: Canadian Journal of Fisheries and Aquatic Sciences, v. 58, no. 6, p. 1208-1221, https://doi.org/10.1139/f01-066.

Vanderploeg, H.A., Liebig, J.R., Nalepa, T.F., Fahnenstiel, G.L., and Pothoven, S.A., 2010, Dreissena and the disappearance of the spring phytoplankton bloom in Lake Michigan: Journal of Great Lakes Research, v. 36, p. 50-59, https://doi.org/10.1016/j.jglr.2010.04.005.

Weber, M.M., 2015, Zequanox application technique pilot study on Lake Erie: Davis, Calif., Marrone Bio Innovations, Inc., MBI Project Number 401-0053, 15 p.

Whitledge, G.W., Weber, M.M., DeMartini, J., Oldenburg, J., Roberts, D., Link, C., Rackl, S.M., Rude, N.P., Yung, A.J., Bock, L.R., and Oliver, D.C., 2015, An evaluation Zequanox ${ }^{\circledR}$ efficacy and application strategies for targeted control of zebra mussels in shallow-water habitats in lakes: Management of Biological Invasions, v. 6, no. 1, p. 71-82, https://doi.org/10.3391/mbi.2015.6.1.06. 


\section{Appendix 1. Detailed Sampling Locations by Treatment for Each Test Plot}

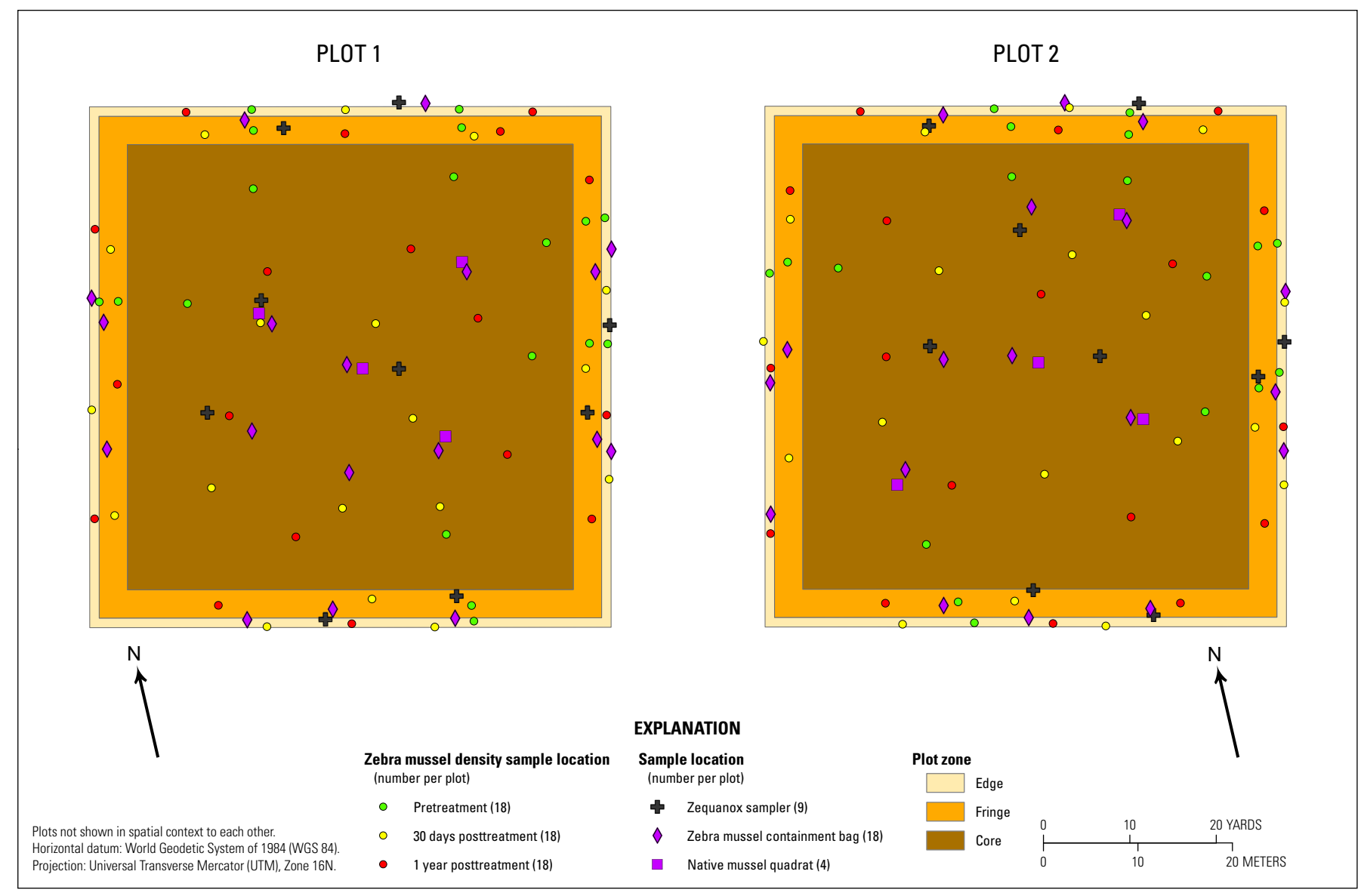




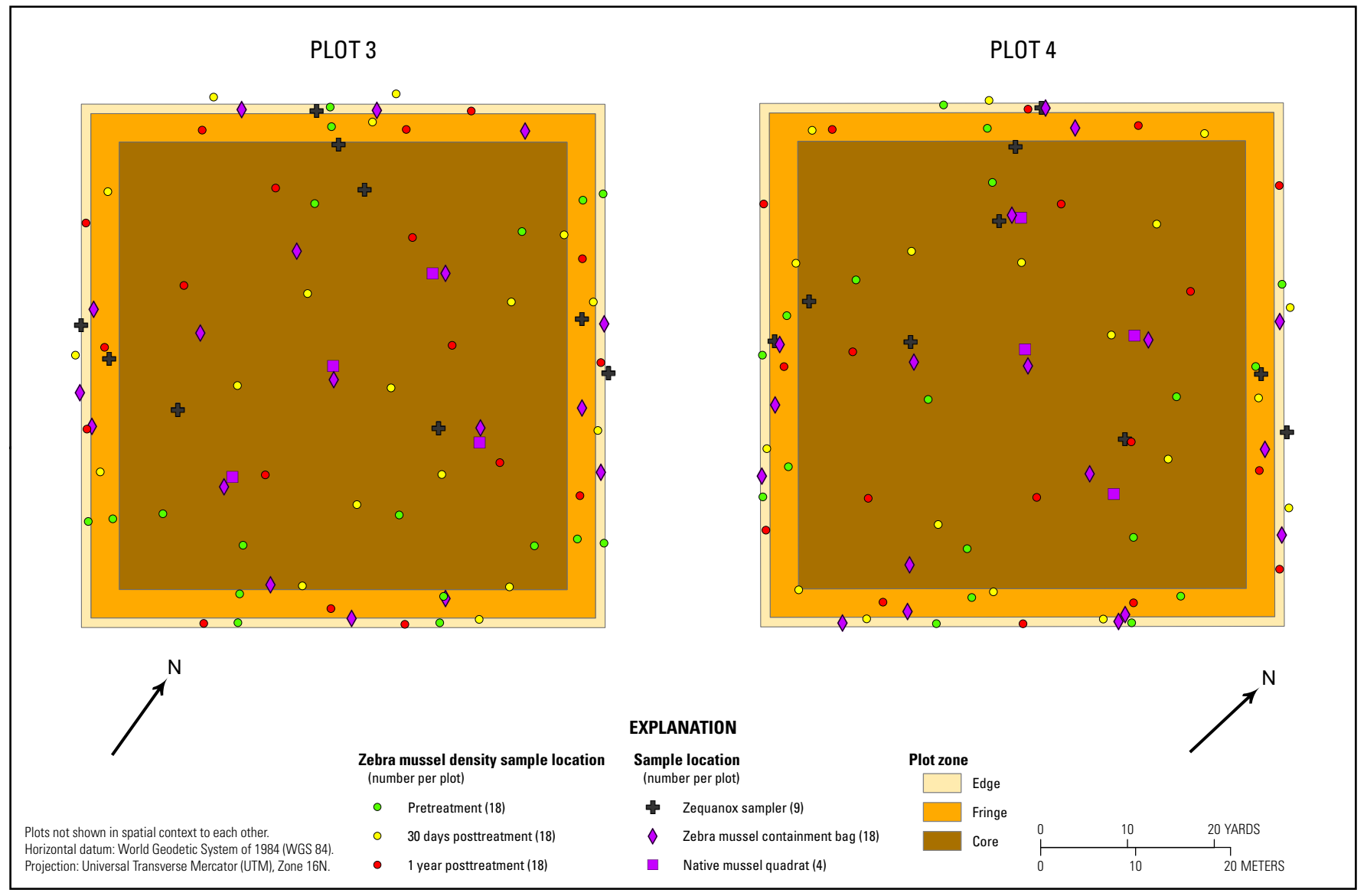




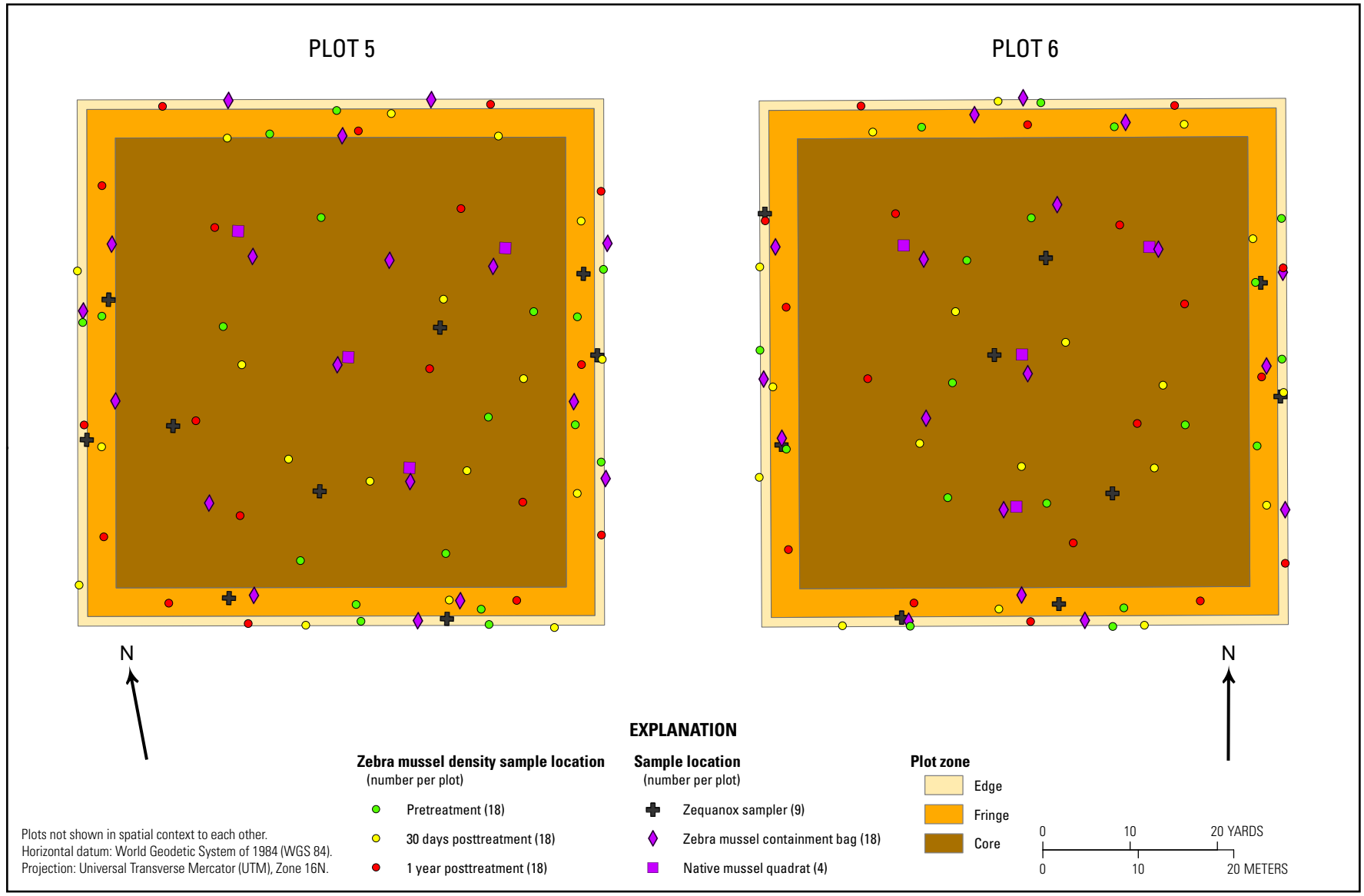


For more information about this publication, contact: Director, Upper Midwest Environmental Sciences Center 2630 Fanta Reed Rd.

La Crosse, WI 54603

608-781-6391

For additional information, visit https://www.usgs.gov/centers/umesc

Publishing support provided by the

Madison and Rolla Publishing Service Centers 



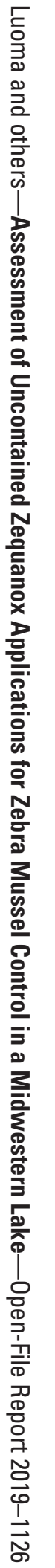

